Review

\title{
The fate of plastic litter within estuarine compartments: An overview of current knowledge for the transboundary issue to guide future assessments ${ }^{\text {hr }}$
}

\author{
L.M. Pinheiro ${ }^{\text {a, b, *, V.O. Agostini }}{ }^{\text {a, }}$, , A.R.A. Lima ${ }^{\text {d }}$, R.D. Ward ${ }^{\text {e, }}{ }^{\text {, G.L.L. Pinho }}{ }^{\text {a }}$ \\ ${ }^{a}$ Laboratório de Microcontaminantes Orgânicos e Ecotoxicologia Aquática - Instituto de Oceanografia - Universidade Federal do Rio Grande (FURG). Av. \\ Itália, Km 8, Carreiros, CEP: 96203-900, Rio Grande, RS, Brazil \\ b Programa de Pós-graduação em Oceanologia (PPGO), Brazil \\ ${ }^{c}$ Programa Nacional de Pós-Doutorado da Coordenação de Aperfeiçoamento de Pessoal de Nível Superior (PNPD-CAPES/PPGO), Brazil \\ ${ }^{\mathrm{d}}$ Marine and Environmental Sciences Centre, ISPA - College Institute, Department of Biosciences, 1149-041, Lisbon, Portugal \\ e Centre for Aquatic Environments, University of Brighton, Cockcroft Building, Moulsecoomb, Brighton, BN2 4GJ, United Kingdom \\ ${ }^{\mathrm{f}}$ Institute of Agriculture and Environmental Sciences, Estonian University of Life Sciences, Kreutzwaldi 5, EE-51014, Tartu, Estonia
}

\section{A R T I C L E I N F O}

\section{Article history:}

Received 27 October 2020

Received in revised form

5 March 2021

Accepted 6 March 2021

Available online 15 March 2021

\section{Keywords:}

Transboundary

Biofouling

Chemical compounds

Macroplastic

Microplastic

Toxicity

\begin{abstract}
A B S T R A C T
Plastics can enter biogeochemical cycles and thus be found in most ecosystems. Most studies emphasize plastic pollution in oceanic ecosystems even though rivers and estuaries are acknowledged as the main sources of plastics to the oceans. This review detected few studies approaching the transboundary issue, as well as patterns of estuarine gradients in predicting plastic distribution and accumulation in water, sediments, and organisms. Quantities of plastics in estuaries reach up to 45,500 items $\mathrm{m}^{-3}$ in water, 567,000 items $\mathrm{m}^{-3}$ in sediment, and 131 items per individual in the biota. The role of rivers and estuaries in the transport of plastics to the ocean is far from fully understood due to small sample sizes, short-term approaches, sampling techniques that underestimate small plastics, and the use of site-specific sampling rather than covering environmental gradients. Microfibres are the most commonly found plastic type in all environmental matrices but efforts to re-calculate pathways using novel sampling techniques and estimates are incipient. Microplastic availability to estuarine organisms and rising/sinking is determined by polymer characteristics and spatio-temporal fluctuations in physicochemical, biological, and mineralogical factors. Key processes governing plastic contamination along estuarine trophic webs remain unclear, as most studies used "species" as an ecological unit rather than trophic/functional guilds and ontogenetic shifts in feeding behaviour to understand communities and intraspecific relationships, respectively. Efforts to understand contamination at the tissue level and the contribution of biofouling organisms as vectors of contaminants onto plastic surfaces are increasing. In conclusion, rivers and estuaries still require attention with regards to accurate sampling and conclusions. Multivariate analysis and robust models are necessary to predict the fate of micro- and macroplastics in estuarine environments; and the inclusion of the socio-economic aspects in modelling techniques seems to be relevant regarding management approaches.
\end{abstract}

(C) 2021 Elsevier Ltd. All rights reserved.

\section{Introduction}

Plastic waste is one of the world's most pressing environmental problems driven by international mismanagement; accounting for

\footnotetext{
This paper has been recommended for acceptance by Eddy Y. Zeng.

* Corresponding author. Programa de Pós-graduação em Oceanologia (PPGO), Brazil.

E-mail address: laramesquita26@gmail.com (L.M. Pinheiro).
}

100 million tonnes found in the oceans (Anderson et al., 2018; Lebreton et al., 2017; Ockelford et al., 2020). Nearly 90\% of this waste enters the ocean from land-based sources as estuaries are the main pathway exporting plastics from the land to the sea (Lima et al., 2020). The bi-directional freshwater-seawater flow creates heterogeneous boundaries with potential to accumulate plastics into these systems. The relative abundance of plastics increases upstream when tidal influx is the main factor structuring the estuarine gradient, and then increases seawards whenever river 
flows break this gradient, as observed for other pollutants worldwide (Lebreton et al., 2017; Lima et al., 2014). This highlights that plastic pollution has a transboundary nature, with complex spatiotemporal patterns that are not fully understood (Krelling and Turra, 2019; Lima et al., 2020). Assessments of riverine systems are rare, which leads to knowledge gaps and estimations of plastic emissions to the oceans (Li et al., 2018a,b). In addition, controversial concepts regarding buoyancy vs. settling hampers accurate predictions concerning the fate of plastics within biogeochemical cycles (Zalasiewicz et al., 2016).

Plastics are ubiquitous and commonly recognized as stratigraphic markers, and they have been used to support the proposal of a new geological epoch called the Anthropocene (Zalasiewicz et al., 2016). Due to their low density and portability, plastic polymers such as polyester (PES), polyethylene (PE), polypropylene (PP), polyvinyl chloride (PVC), polystyrene (PS) are readily found in every aquatic environment (Wang et al., 2018). Once in the aquatic environment, plastics typically break down into smaller fragments, known as microplastics ( $<5 \mathrm{~mm})$. Microplastics' size can be compared to plankton $(<0.2 \mu \mathrm{m}$ to $>20 \mathrm{~cm})$ or even sediment grains (fine gravel to clay $-0.98 \mu \mathrm{m}$ to $8 \mathrm{~mm}$ ), which influences their capacity to cause harm, to become bioavailable and to be transferred along the trophic web (Crooks et al., 2019; Farrell and Nelson, 2013; Murray and Cowie, 2011; Ferreira et al., 2019a).

This work provides a critical review of knowledge gaps regarding plastic contamination in estuarine ecosystems, especially concerning methodological efforts, composition, toxicity and interaction with biota and other contaminants through estuarine compartments. A total of 133 selected publications in 46 journals (Table S1) from studies in 26 countries were evaluated (Fig. 1). These ranged from 1972 until our pre-established time limit of September 2020 (Figure S1). Details of the search methods can be found in the supplementary material.

\section{Plastic contamination from rivers to estuaries}

It is estimated that $57,000-265,000$ MT of plastic entered the oceans from riverine systems in 2018, according to a recent model considering the Human Development Index (HDI) (Mai et al., 2020). These estimates are much lower than those reported by Lebreton et al. (2017) (1.15-2.41 million MT year ${ }^{-1}$ ), which are based on annual production and the concept of Mismanaged Plastic Waste (MPW). However, the strong correlation between model estimates and field measurements $\left(r^{2}=0.71\right)$ suggests that HDI models are better indicators to estimate global riverine plastic outflows. Asian rivers accounted for $\sim 69 \%$ of the total global input, suggesting discharges of up to 173,000 MT year ${ }^{-1}$. The remainder comes from South America (13\%), North (7.1\%) and Central America (5.5\%), Europe (5\%), and Africa and Oceania (0.5\%) (Mai et al., 2020).

Estimates concerning microplastic inputs are still doubtful (Bellasi et al., 2020; Li et al., 2018a,b; Strungaru et al., 2019). The abundance of microplastics reported by studies using pumping or grab are at least three orders of magnitude higher than those collected with plankton net tows, as small sized plastics and flexible fibres are not efficiently collected by nets even though they represent $>50 \%-90 \%$ of the microplastic present in the aquatic ecosystems (Lima et al., 2021). In the Austrian Danube (Austria) and Grand Paris, microplastics had an average abundance of 0.317 and 30 items $\mathrm{m}^{-3}$ when collected with plankton nets with mesh sizes of $80 \mu \mathrm{m}$ and $500 \mu \mathrm{m}$, respectively (Dris et al., 2015; Lechner et al., 2014), but this increased up to 2516.7 items $\mathrm{m}^{-3}$ in the Yangtze river (China) (Zhao et al., 2014) and up to $10^{5}$ items $\mathrm{m}^{-3}$ in the Dutch River Delta and Amsterdam Canals (Leslie et al., 2017), when samples collected by water pumping were passed through a $32 \mu \mathrm{m}$ sieve and filtered over a $0.7 \mu \mathrm{m}$ glass filter, respectively. Although comparisons between methods must be performed at least in the same region and between similar size ranges, it is likely that microplastic emissions have been underestimated due to the high divergence in abundances estimated by different methods,

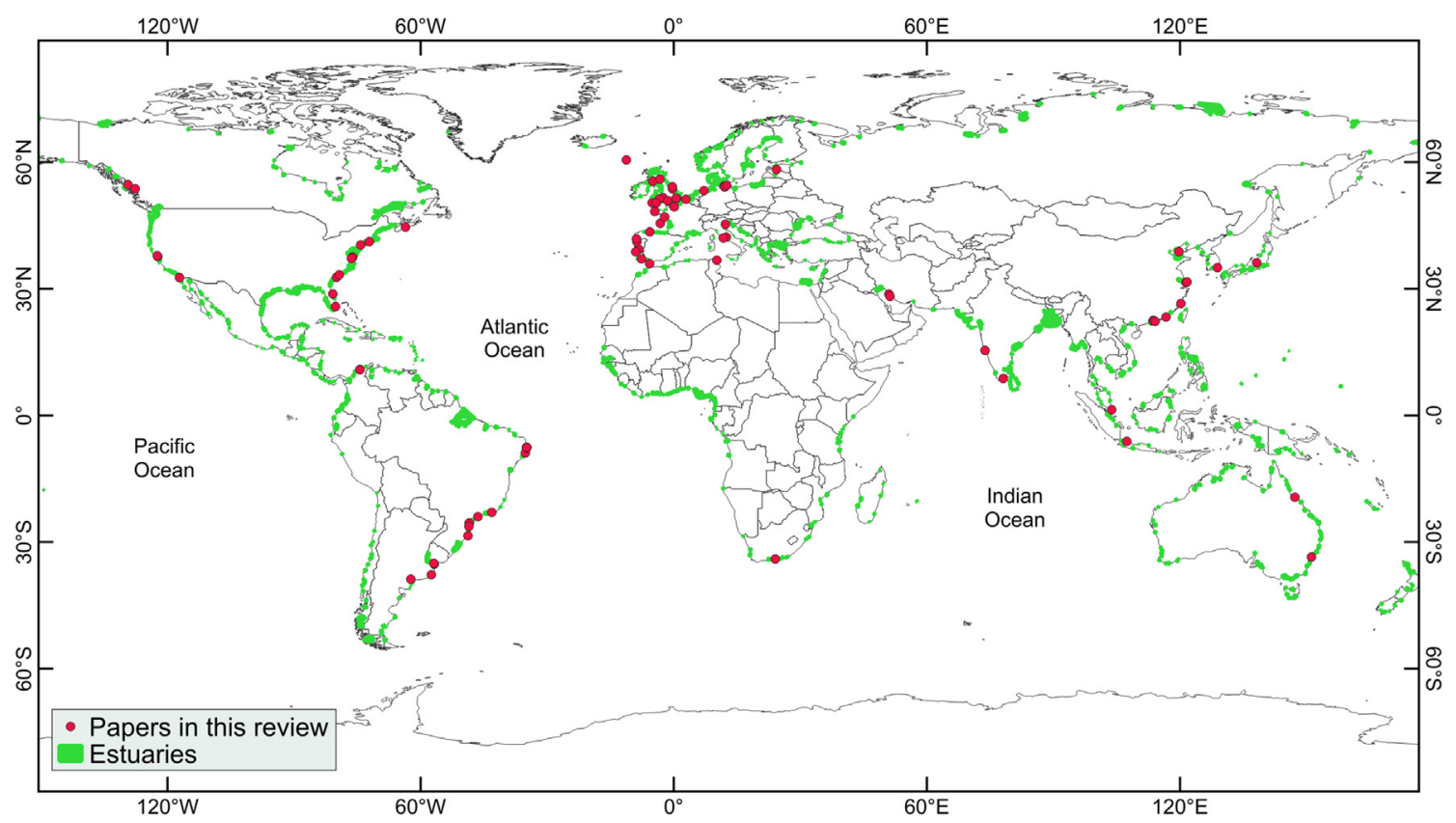

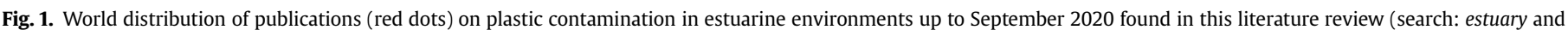

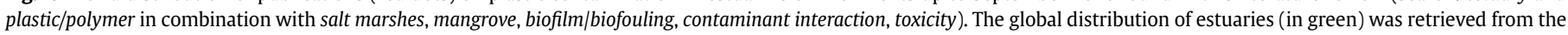

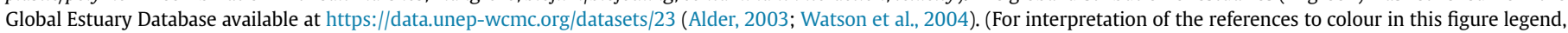
the reader is referred to the Web version of this article.) 
regardless of the riverine system (Li et al., 2018a,b). Therefore, efforts to understand smaller-size plastic emissions are still necessary (Blettler et al., 2018).

Little is known about plastic pollution in riverine sediments in comparison to water. In the Thames River (UK), for example, microplastic concentration ranged between $18.5 \pm 4.2$ and $66 \pm 7.7$ items per $100 \mathrm{~g}$ of dry sediment (1000 to $4000 \mu \mathrm{m}$ ) (Horton et al., 2017). In the Rhine and Main rivers (Germany), microplastic concentration varied from 1,784 to 30,106 items $\mathrm{m}^{-2}(63-5000 \mu \mathrm{m})$ (Klein et al., 2015). Although methodological comparison is not possible, it is interesting to note that fibres and fragments were the most common types in both studies, and sources were related to domestic effluents and local breakdown, respectively.

Fragments and fibres are commonly found in freshwater systems. Tyre wear particles (TWP, $<2.5 \mu \mathrm{m}$ ) account for $5-10 \%$ of all microplastics originated in land and ending up in the oceans (Bellasi et al., 2020). In Germany, 11,000 tons year ${ }^{-1}$ of TWP reach surface waters through rainwater runoff (Bellasi et al., 2020). Another important source of microplastics are Wastewater Treatment Plants (WWTPs), especially in highly populated areas in developing countries, where microbeads and microfibres are the main contaminants. Microplastic emissions through WWTPs have

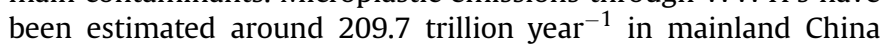
(Cheung and Fok, 2017); 50,000 - 15 million microplastics day ${ }^{-1}$ in the United States (Mason et al., 2016), and 30 billion microplastics year $^{-1}$ in Vancouver (Canada) (Gies et al., 2018). Washing machines also discharge large amounts of synthetic fibres into wastewater that eventually reach aquatic systems (Dris et al., 2015). Synthetic fibres represent $60 \%$ of the 9 million tons of fibres produced worldwide, and approximately 2.5 million tons year ${ }^{-1}$ of polyester fibres enter the oceans via river input (Carr, 2017).

\section{The occurrence of plastics in estuaries}

\subsection{Modelling the distribution and accumulation of plastics in estuaries}

Few studies have implemented modelling techniques to investigate plastic distribution and accumulation in estuaries according to spatial and temporal factors (Waldschläger et al., 2020). Hydrodynamic models are, for instance, useful tools to predict particle tracking, including Lagrangian and Eulerian approaches; and these have been widely used to simulate the pathways of plastics according to estuarine physical properties (Cohen et al., 2019; Krelling et al., 2017). However, processes such as the influence of rainfall, tidal waves and flow rates are still not well discussed because correlative modelling is missing (Lourenço et al., 2017; Naidoo et al., 2015).

Large plastics are easy to track, and most studies investigating macroplastic pollution have focussed on understanding how urbanization, industrialization, and proximity to Wastewater Treatment Plants influence accumulation patterns (Nelms et al., 2020; Viehman et al., 2011; Willis et al., 2017a). In the lower Paranaguá estuary (Brazil), for example, large plastic fragments dominate marine debris (74.8\%) (Krelling and Turra, 2019). For this estuary, debris are exported seaward after a residence period of 5 days, as revealed by a simplified hydrodynamic model of dispersion (Krelling et al., 2017). Once in the outer estuary, no movement upstream was observed and, thus, the ocean is suggested to act as a sink. The study highlights that transboundary approaches must be implemented to manage marine debris across the land-river-sea continuum (Krelling et al., 2017).

Tracking microplastic distribution is far more difficult as a result of the high number of types and sources, fragmentation routes, and the complex relationship between abundance and physico- chemical factors within aquatic systems. Tyre and road wear particles (TRWP) degrade to smaller particles with estimates of $1.8 \mathrm{~kg}$ inhabitant ${ }^{-1} \mathrm{yr}^{-1}$ in the Seine watershed (France), as revealed by a geospatially- and temporally-resolved mass balance model (Unice et al., 2019). The model considers terrestrial transport to soil, air and roadways, and freshwater transport processes. These estimates indicate that $49 \%$ of TRWP produced on the road are transported to freshwater systems, $19 \%$ is transported through rivers, and $\sim 2 \%$ is eventually exported to estuaries.

In Delaware Bay (USA), 3D hydrodynamic simulations applying a regional ocean modelling system within the Coupled-OceanAtmospheric-Wave-Sediment Transport Modelling System were performed to determine the transport and distribution of positively buoyant microplastics (Cohen et al., 2019). The model suggested that microplastics quickly organize into hotspots with high spatial and temporal variability influenced by currents, winds and tides; and the upper bay was found to have the highest microplastic densities. However, physical process such as river runoff influences were not identified due to limited and short-term sampling design (Cohen et al., 2019).

Both sediment and water samples were evaluated in five estuaries in Durban (South Africa) to understand patterns of microplastic accumulation under a simple spatial approach (Naidoo et al., 2015). Significant differences were observed among different estuarine reaches, but the Durban Bay estuary presented the highest abundance of microplastics (up to $7.4 \pm 1.3 \times 10^{-6}$ particles $\mathrm{m}^{-3}$ ). Microplastics had a positive relationship with the large number of stormwater outfalls and rivers that drain into the Durban harbour. In the Tejo Estuary (Portugal), the distribution of microfibres was investigated in intertidal sediments using a General Linear Model (Lourenço et al., 2017). The spatial distribution of microfibres was positively influenced by the percentage of fine sediments (characterizing areas of slow current velocity), and by human settlement in adjacent areas. This suggests that hydrodynamics, local domestic sewage, and textile washing were the main factors influencing the distribution of microfibres.

Given the assumptions reported using modelling approaches, it is not surprising that more studies on plastic dynamics are still necessary to fully address their fate in estuaries (Ockelford et al., 2020). Although it was expected that sediments may be the final sink for microplastics (Van Cauwenberghe et al., 2013), more recent studies suggest that this might not be true for all polymers especially buoyant polymers (Erni-cassola et al., 2019). Therefore, driving forces influencing polymer distribution need to be evaluated as a whole considering as many steps of biogeochemical cycles as possible.

\subsection{Methodologies to estimate plastic contamination in estuarine environments}

\subsubsection{Size categories}

There appears to be a consensus about the upper limits of micro and nanoplastics but not meso and macroplastics (Table S2). A division between macroplastics $(>5 \mathrm{~mm})$, microplastics $(1 \mu \mathrm{m}-5 \mathrm{~mm})$ and nanoplastics $(1 \mathrm{~nm}-1000 \mathrm{~nm})$ was therefore used in this review.

Fewer papers on macroplastics (25.5\%, considering plastics and debris in general) in estuaries were retrieved compared to microplastics (82.7\%). This reflects the interest in microplastics in recent years (2014 onwards, Figure S1), which is justified by the interest in ingestion as microplastics are harmful to smaller estuarine species as planktonic organisms that can ingest particles even in the nanosize range (Rist et al., 2017). However, no papers discussed nanoplastics in estuarine environments, which is likely due to methodological limitations to analyse such particles in environmental 
samples (Koelmans et al., 2015; Mattsson et al., 2018). Attention appears to be directed towards lower trophic levels (see "The presence of plastics in estuarine biota"), since they represent a base link to the trophic web and microplastics are potentially more harmful to these organisms. However, $9 \%$ of studies did not specify the size of the debris analysed, leading to inconclusive results regarding effects to biota (Ye and Andrady, 1991; Turner et al., 2015).

\subsubsection{Water sampling in estuaries}

Water quality in estuaries is often defined by local climates, sediment cycles, fluctuation of physicochemical parameters, and human changes (Lima et al., 2020; Seeliger et al., 1998; Ward et al., 2014, 2016). The salinity gradient, which also influences parameters including $\mathrm{pH}$ and suspended material (through flocculation), is also acknowledged to induce particle movement in the water column (Niencheski and Windom, 1994). Indeed, it has been shown that litter accumulates in saline fronts, probably related to the low circulation and high sedimentation rates normally found in these areas during drought periods (Acha et al., 2003).

Saline fronts, also named as estuarine turbidity maximum (ETM) zones, can vary in their position dependent on the river/ ocean flow balance (Day et al., 2013). In macrotidal estuaries, the volume of water exchanged between river and ocean during tidal cycles is much higher than in microtidal estuaries, where other factors such as rain and wind patterns will determine the flow balance and consequently the salinity gradient (Ward et al., 2016). The presence of an ETM zone and associated factors and temporal conditions should therefore be considered in investigations concerning suspended contaminants, especially because small-sized plastics seems to have a positive correlation with the amount of fine sediments (Lourenço et al., 2017).

Plastic contamination in estuaries can be assessed directly using water samples. In this review, four papers quantified macroplastics in estuarine water. Sadri and Thompson (2014) used a manta $(300 \mu \mathrm{m})$ net to collect plastic debris from surface water of the Tamar estuary (UK). Although they found mostly microplastics (82\%), particles $>5 \mathrm{~mm}$ were also sampled and quantified. Morrit et al. (2014) used modified fyke nets, used for fishing, to trap macro-litter items for almost three months in the River Thames (UK). All litter collected in that survey was submerged (the net was deployed at a depth of $40 \mathrm{~cm}$ ), and not on the river surface.

Plastic items can have their density altered by degradation and/ or biofouling, while water density variations in estuaries are dominated by salinity (Maccready et al., 2018), which is influenced by freshwater/seawater inflows. The differences between plastic density and water density will determine their buoyancy, and therefore need to be considered in such studies. Yet, contamination studies should also consider different depths inside the water matrix i.e. the feeding zones of burrowing organisms where plastic particles can accumulate due to bioturbation activity (Näkki et al., 2017; Gebhardt and Forster, 2018).

Microplastics are usually isolated from water samples using filtration/sieving methods. In this review, the most common sampling devices were nets with $300-333 \mu \mathrm{m}$ mesh size. This is recommended by the Guidance on Monitoring of Marine Litter in European Seas for microplastic sampling in seawater (Galgani et al., 2013 ) in order to increase comparability. However, most fibres can pass through this mesh due to flexibility and small size; therefore, quantities of microfibers estimated using these methods are probably highly underestimated (Lima et al., 2021). Posterior filtration using sieves or paper filters with mesh sizes varying from $0.02 \mu \mathrm{m}$ to $3 \mathrm{~mm}$ were also used (see Table S3).

The studies from two papers used water pumps to collect microplastic samples from estuarine water (Zhao et al., 2014, 2015).
This method has the advantage of a precise volume filtered through the pump, so reported results are more reliable for fibres. Also, Setälä et al. (2016) have compared this method with manta trawl sampling and stated that pumps allow method control, use of different filter sizes and sampling at different depths. However, water collection through pumping must be performed under a continuous sampling intake to allow the coverage of a larger area, as plankton tows do, rather than the collection of point samples. Therefore, coupling plankton tows and pumping methods for water samples is a good step to guarantee accurate quantifications of the diversity of microplastics found in aquatic systems.

Initially microplastics were assessed as a sub-product of plankton surveys. Now they are being targeted at their own right, which explains why most studies used sampling with nets (Table S3). Consequently, a great amount of organic material in the same size class is collected together with microplastics. Therefore, methods are required to clean up samples to allow for effective polymer characterization. Three papers used digestion with hydrogen peroxide $\left(\mathrm{H}_{2} \mathrm{O}_{2}\right)$ to minimise biological interference in water samples for microplastic analysis (Stolte et al., 2015). This is a common method for removing organic material in sediment analysis (Jensen et al., 2017), and therefore it is especially encouraged in highly productive environments, such as estuaries (Day et al., 2013) as it can help sample characterization and further microplastic identification, increasing the reliability of results.

\subsubsection{Sediment sampling in estuaries}

Sediments in estuaries are derived from river input, erosion, primary production, the sea and the atmosphere, although mudflats can be important lateral sediment sources when present in estuaries (Schubel, 1982). Estuaries can entrap sediments during low river flow, where they accumulate before entering the oceans when runoff increases seaward (Ward and Lacerda, 2021). This process has been used to explain patterns of dispersal of suspended solids and contaminants such as heavy metals (Teuchies et al., 2013; Celis-Hernandez et al., 2020a; Lacerda et al., in press), and can therefore be extended to plastics.

To perform sampling of macroplastics in sediment, collection using transects appeared to be the most common procedure in estuaries (e.g. Araújo and Costa, 2007; Ivar do Sul and Costa, 2013). This method allows a quick visual identification and sampling of plastic items in the environment, which can be analysed in the field or taken to a research facility for posterior analysis. Parameters such as number of items per unit area, item size, degradation stage and possible source are commonly used to describe environmental macroplastics and therefore to report a contamination scenario of the area. For microplastics, the great majority of works dealt with superficial layers of sediment (up to $5 \mathrm{~cm}$ deep) (e.g. Vianello et al., 2013; Talley et al., 2020), which are expected to comprise recent deposition of contaminants (Zalasiewicz et al., 2016). Usually sampling is performed in quadrats, with the sediment collected using grabbers or simple instruments like shovels, so the results are usually reported in number of microplastics per unit of area (e.g. Fok and Cheung, 2015; Fok et al., 2017; Cheung et al., 2016).

Both transects and quadrats represent simple methods for plastic sampling providing comparability among studies. However, estuarine regions have many different scenarios of tidal regimes, flooding rates and vegetation, and these must be considered in order to select an adequate sampling strategy. For example, sediment in estuaries can be found covered by a significant plant litter layer in salt marsh environments (Adam, 1993). In areas where this occurs, these different compartments (sediment/plant litter) should be considered individually when analysing plastic contamination, as the deposition times and dynamics are likely to differ among them (Ward et al., 2014; Ward, 2020). 
In order to isolate microplastic particles from sediment, it is very common to use saline flotation techniques followed by filtration, using high density solutions that allow lighter plastic particles to float. Fok and Cheung (2015) isolated microplastics from sediment using seawater from their sampling site. This likely allowed the isolation of both lighter plastic items and items whose original polymer density was higher than seawater density but were weathered and became lighter. Thus, this methodology is appropriate for lower parts of the estuary, where seawater has a stronger influence and therefore a greater amount of plastics are likely to float. However, in the upper parts of the estuary, where seawater intrusion is low or non-existent, this method may not be as efficient due to a lower freshwater density $\left(\sim 1.0 \mathrm{~g} \mathrm{~cm}^{-3}\right)$.

For other saline solutions, preparation can require various salts such as $\mathrm{NaCl}\left(1.0-1.2 \mathrm{~g} \mathrm{~cm}^{-3}\right), \mathrm{Na}_{2} \mathrm{WO}_{4} \cdot 2 \mathrm{H}_{2} \mathrm{O}\left(1.40 \mathrm{~g} \mathrm{~cm}^{-3}\right), \mathrm{NaBr}$ $\left(1.37-1.40 \mathrm{~g} \mathrm{~cm}^{-3}\right), \quad 3 \mathrm{Na}_{2} \mathrm{WO}_{4} \cdot 9 \mathrm{WO}_{3} \mathrm{H}_{2} \mathrm{O} \quad\left(1.40 \mathrm{~g} \mathrm{~cm} \mathrm{~cm}^{-3}\right)$, $\mathrm{Li}_{6}\left(\mathrm{H}_{2} \mathrm{~W}_{12} \mathrm{O}_{40}\right)\left(1.6 \mathrm{~g} \mathrm{~cm}^{-3}\right), \mathrm{ZnCl}_{2}\left(1.6-1.8 \mathrm{~g} \mathrm{~cm}^{-3}\right), \quad \mathrm{ZnBr}_{2}$ $\left(1.7 \mathrm{~g} \mathrm{~cm}^{-3}\right)$, and $\mathrm{NaI}\left(1.80 \mathrm{~g} \mathrm{~cm}^{-3}\right)$ (Frias, 2018). Interestingly, most papers ( 9 of 17 using saline flotation) in this review used $\mathrm{NaCl}$, with three papers using $\mathrm{NaI}$, two using $\mathrm{ZnCl}_{2}$, and the other three papers using other solutions (Table S3). The $\mathrm{NaCl}$ solution may still be largely in use due to its low cost and efficiency, this method has been found to be highly efficient at isolating microplastics, although $\mathrm{ZnCl}_{2}$ is more efficient for denser polymers (Coppock et al., 2017). Plastic particles in estuaries are likely to undergo high degradation levels due to physical forces such as periodical sunlight exposure and abrasion and thus their density may be lower than in other environments, so a lower density solution may be suitable to catch these items (Erni-cassola et al., 2019).

For sediment samples, digestion procedures can also be used to remove biological material and enhance plastic identification, including $\mathrm{H}_{2} \mathrm{O}_{2}$ (Jensen et al., 2017). However, only four papers in this review used such technique for this type of matrix (Table S3). According to the authors, this prevented large amounts of organic matter interfering with plastic isolation during the density separation process and subsequent counting. In addition, treatment with $\mathrm{H}_{2} \mathrm{O}_{2}$ can help remove natural coating such as biofilms on plastic surface (Christensen et al., 1990), which can make them resemble natural particles and be missed during visual identification (Isobe et al., 2019).

The sedimentation process is highly influenced by the action of waves, tides, atmospheric pressure and currents (Teasdale et al., 2011; Ward et al., 2014, 2016; Lima et al., 2020). As estuaries are very dynamic, sediment deposition is highly influenced by those forces and can vary greatly within the sediment column (Willis et al., 2017b). Sediments deposited on the surface can be translocated to deeper layers through sediment mixing or bioturbation processes (Martinetto et al., 2016; Ward, 2020), taking plastic particles with it. Extreme events such as storms and typhoons can cause stratigraphic mixing, even if the area is protected by vegetation such as salt marshes (Feagin et al., 2009; Li et al., 2020a). Also, sediment permeability can differ among sediment types and depths, which has also been suggested to influence microplastic dynamics (Misic et al., 2019). Therefore, although it may be very difficult to correlate plastics and sediment deposition rate, it is quite important to analyse deeper fractions of sediment in order to fully understand microplastic dynamics in estuaries, as has been undertaken for other contaminants (Cundy and Croudace, 1996; Celis-Hernandez et al., 2020a,b).

\subsubsection{Laboratory and field experiments under estuarine conditions}

Laboratory experiments were described in seventeen papers retrieved in this review. One paper used estuarine sediment to investigate bacterial colonization on microplastic particles in a microcosm system (Harrison et al., 2014), while two others investigated sorption aspects of the interaction between heavy metals (Holmes et al., 2014) and organic compounds (Bakir et al., 2014) with microplastics. We could only identify two works that have performed laboratory feeding trials using estuarine species (Table S3), although a recent study has assessed the trophic buildup of microplastics from Mytilus edulis to Necora puber through predation (Crooks et al., 2019). These approaches are important to answer specific questions by isolating factors of interest, and they will be discussed in further sections in this review.

Experimental procedures performed in the field were described in four papers (see Table S3 for details). They involved implantation of plastic items in the environment for different purposes. Two papers investigated the biofouling process in macroplastic items (Lobelle and Cunliffe, 2011; Ye and Andrady, 1991). One interesting work observed the formation of microplastics from implanted macroplastics in a salt marsh environment (Weinstein et al., 2016), but they did not quantify these particles in the environment.

One paper used a different approach in their field experiment, performing a recovery experiment by releasing tagged macroplastic items in a mangrove unit in Northeast Brazil and then recollecting them six days (Ivar do Sul et al., 2014). Their strategy was defined to understand the retention and exportation capacity of that specific environment, and therefore they did not quantify actual amounts of plastic litter in the environment, water or sediment. However, they showed how plastic contamination was influenced by hydrodynamics and vegetation, with more items being trapped in higher elevation areas, with weaker currents and denser vegetation. This recognized the role of vegetation in trapping debris on estuarine areas, as also observed by Araújo and Costa (2007) and similar to the processes influencing sediment (Ward et al., 2014), showing that vegetation is a key factor influencing plastic dynamics in estuaries.

Most of the aforementioned works were the result of field investigations (58.7\%), with a few others conducting laboratory experiments (12.8\%). Although these are very informative, some uncertainties remain about how plastic contamination can alter and affect estuarine environments and associated organisms. Experiments performed in natural environments under semicontrolled conditions can be considered a very useful strategy to answer questions that cannot be fully assessed with other approaches alone because it portrays the multi-faceted processes that plastic items suffer in estuarine environments.

\subsection{Factors influencing plastic quantities in estuaries}

In our literature review, 41 and 31 studies out of 100 papers quantified plastic in sediment and water, respectively. The abundance of macro and microplastics found in the studied estuarine matrices are shown in Tables S4 and S3, respectively, reaching up to 567,000 items $\mathrm{m}^{-3}$ in sediment and 45,500 items $\mathrm{m}^{-3}$ in water. Morritt et al. (2014) quantified macro litter in the upper portion of the Thames river estuary (UK) where a total of 8,490 items were collected inside the river catchment in three months using a pyke net with a non-specified mesh size. In sediments, abundance of macroplastics (manually collected) ranged from $<0.1$ items $\mathrm{m}^{-2}$ in an isolated Brazilian beach (Araújo and Costa, 2007) up to $163 \pm 154$ items $\mathrm{m}^{-2}$ in the at the Pearl River Estuary (China) (Fok et al., 2017), where plastics from 0.315 to $10 \mathrm{~mm}$ were visually sorted in the top $4 \mathrm{~cm}$ of sediment (Table S4). Regarding microplastics (Table S3), the Mtamvuna River estuary (South Africa) had the highest contamination per volume of sediment $\left(567,000\right.$ items $\left.\mathrm{m}^{-3}\right)$, collected to a depth of $5 \mathrm{~cm}$, sieved through a $1 \mathrm{~mm}$ mesh sieve and isolated using a $\mathrm{NaCl}$ solution (De Villiers, 2019). The Mosquito Lagoon in the northern Indian River Lagoon system, Florida (US), had the highest microplastic abundance per volume in water (up to 45,500 
items $\mathrm{m}^{-3}$ ), which was collected with bottles and filtered through a $0.45 \mu \mathrm{m}$ mesh (Waite et al., 2018). The least contaminated areas were the Bay of Brest (France), with $0-8.74$ items $\mathrm{kg}^{-1}$ of dry sediment collected with a Van Veen grab, from which microplastics were isolated using $\mathrm{NaCl}$ and $\mathrm{Na}_{2} \mathrm{WO}_{4}$ solutions followed by filtration with a $1.6 \mu \mathrm{m}$ mesh size (Frère et al., 2017), and the Citarum River (Indonesia) with $0.000666 \pm 0.000577$ items $\mathrm{m}^{-3}$ of water, collected with a manta trawl $(125 \mu \mathrm{m}$ mesh) and a grab sampling method, from which microplastics were isolated visually (Sembiring et al., 2020).

It is inconclusive to compare microplastic abundance between sediments and water samples due to divergences in sampling methods, sampling sizes and sampling designs. Physical properties of an estuary such as tidal movements, currents, river discharge and winds have a strong influence on water flow, in a way that sampling in water only portrays a snapshot of the contamination. Also, microplastics can overlap in size and settling rates with sediment particles (Vermeiren et al., 2016), so forces acting on the sediment particles can also act on microplastics.

The transfer of energy, material and organisms between the water column and the benthic environment, i.e. the benthic-pelagic coupling, is an important process that occurs in estuaries (Griffiths et al., 2017). Plastic items in estuarine water or sediment can therefore be influenced by several processes included in the benthic-pelagic coupling such as sinking (Kaiser et al., 2017), (re) suspension (Critchell and Lambrechts, 2016), bioturbation (Näkki et al., 2017), among others (Wolanski and Elliot, 2015). Studies analysing surface sediments should be concerned about the exchange of plastics with water and the influence of estuarine organisms on these processes.

Similar forces may have implications on both sediment and microplastic deposition through the sediment column (Chubarenko et al., 2018; Willis et al., 2017b). Few studies looked at the sediment column below the surface in sandy beaches (e.g. Turra et al., 2014). Two papers investigated plastic in deeper sediment layers in estuaries, with quantities varying from 4.8 to 15.9 items $\mathrm{m}^{-3}$ up to $20 \mathrm{~cm}$ depth in a mangrove (Costa et al., 2011) and more than $100 \mathrm{~g}$ of plastics accumulated to a depth of $50 \mathrm{~cm}$ in a mudflat (Iribarne et al., 2000). Researchers should also consider local hydrodynamics before associating plastic deposition with time, as sedimentation rates in estuaries can vary greatly as a result of river flow variability (Butzeck et al., 2014; Ward, 2020), and mixing might occur due to dredging and fishing devices, such as bottom trawls (Bardos et al., 2020). Bioturbation activity of sedimentdwelling species can bury synthetic particles (Gebhardt and Forster, 2018), e.g. the burrowing activity of the intertidal crab Neohelice granulata can trap debris inside the sediment of salt marshes (Iribarne et al., 2000), and therefore needs to be considered. Solid materials can also be retained by estuarine vegetation (Ivar do Sul et al., 2014), and it is reasonable to relate these interactions with particle size according to species and distance from open water (Ward et al., 2014). Therefore, it is suggested that research in this subject should increase in quality in order to couple all information into single predictions instead of simple quantifications as observed until recently.

\section{The presence of plastics in estuarine biota}

In this review, both macro and microplastics contaminated organisms that inhabit estuaries (e.g. Dantas et al., 2019; Kazour et al., 2020). The most common approaches were analysis of the stomach content (e.g. Kartar et al., 1976; Possatto et al., 2011) and digestion with $\mathrm{H}_{2} \mathrm{O}_{2}$ of the whole organism (e.g. Pazos et al., 2017; Waite et al., 2018). A combination of digestion with saline flotation followed by filtration also seems to be a suitable option to analyse microplastics in tissues (Mathalon and Hill, 2014). In addition, a few studies have analysed excrement for plastic presence (Bravo Rebolledo et al., 2013; Mathalon and Hill, 2014) and even brain tissue (Crooks et al., 2019).

Given that plastics can be found in animals' stomach, tissues or excrements, plastic contamination is likely to negatively affect aquatic organisms. The toxic effects of plastic contamination can include lower feeding activity and loss of energy budget (Wright et al., 2013a), immune responses and oxidative stress (Avio et al., 2015; Canesi et al., 2015), and changes in metabolic rates (Green et al., 2016).

These effects have been shown for fully marine species but the information available for estuarine biota is limited to 34 studies looking at presence inside the organism, and only seven which have looked at the impact. For example, 17 works showed plastic ingestion by estuarine fish (e.g. Possatto et al., 2011; Ramos et al., 2012), but only 2 investigated effects. Dantas et al. (2019) looked at alterations in the condition factor (CF), which is a measure of health considering the weight and length for the Guri sea catfish Genidens genidens as proposed by Richardson et al. (2011). They found lower CF values related to plastic ingestion, while Miranda et al. (2019) showed a reduction in post exposure predatory performance and acetylcholinesterase activity (an enzyme used in neurotransmission) in the common goby Pomatoschistus microps. For other groups, microplastic exposure caused oxidative stress for the peppery furrow shell clam Scrobicularia plana (O'Donovan et al., 2018) and decrease in coelomocytes viability in the polychaete Hediste diversicolor (Revel et al., 2020).

Ingestion can result in direct physical harm to the animal's gastrointestinal tract such as obstruction or internal abrasions, and can ultimately result in death (Wright et al., 2013b). Besides that, during production of polymeric materials many additives such as plasticizers, stabilizers, antioxidants and biocides are commonly used (Hahladakis et al., 2018). These chemicals can be released to the environment due to plastic degradation and can also be toxic to the estuarine biota (Anbumani and Kakkar, 2018; Celis-Hernandez et al., 2020b).

Whilst it is important to understand the impact of microplastic ingestion by estuarine species, there are some limitations to field studies. There is an ethical issue about animal handling, as the procedures for plastic analysis are invasive and mainly lethal. Sampling faeces and other residues may be a good alternative but does not provide a full perspective as animals can retain plastic particles (Gebhardt and Forster, 2018). The effects of ingestion and trophic transfer of plastic items amongst estuarine organisms in the field have not been directly assessed.

Ingestion of plastic particles by both freshwater (e.g. Andrade et al., 2019) and marine organisms (e.g. Hall et al., 2015) have been previously reported and reviewed (Wagner et al., 2014; Wesch et al., 2016). We identified two papers analysing the ingestion of macroplastics. Guebert-Bartholo et al. (2011) investigated the stomach content of the green turtle (Chelonia mydas) in a Brazilian estuary, finding plastics in their gut. Although the green turtle is considered a marine species, the individual studied was part of a group that performs their foraging activities in this estuary. Bravo Rebolledo et al. (2013) investigated stomach, intestine, scats from the harbour seal (Phoca vitulina), finding plastics in 11\% of individuals' stomachs, $1 \%$ for intestines, and $0 \%$ for scats. The investigation of plastic ingestion in marine/freshwater species that visit estuaries is important as they can be part of the plastic cycling in these environments, either removing plastics through ingestion or depositing them through excretion.

We identified 25 papers reporting microplastic ingestion by estuarine species, distributed in many animal taxa with different feeding habits (Table S5). Although microplastic abundance in 
organisms is commonly reported in percentage of individuals containing plastics (see Table S5), this type of representation is not comparable among species as they vary in size and therefore have different uptake capacities. However, a comparison can be made by analysing the percentage of organisms of different feeding guilds or trophic levels, for example, to have an idea of what group is more affected by this type of contamination.

The abundance of microplastics varied from 0 to 131 items per individual in predators (fishes and seals) and from 1.4 to 36 items per individual in deposit and filter feeders (bivalves and polychaetes) (Table S5). These differences point to an expected scenario where organisms in higher trophic levels (predators) tend to ingest more contaminants than animals in lower trophic levels (filter/ deposit feeders). However, one should not compare these directly as plastics were analysed in different body parts: digestive tract for predators, whole organisms for filter feeders and excrement for deposit feeders. Yet, the trophic transfer of microplastics have been demonstrated in the laboratory (Crooks et al., 2019; Farrell and Nelson, 2013; Santana et al., 2017), but deeper investigation of consequences for estuarine species are still lacking.

In the Goiana Estuary (Brazil), at least eleven fish species were evaluated in order to understand how seasonal patterns of estuarine use by different phases of their life cycle affects rates of microfiber ingestion (Dantas et al., 2012; Ferreira et al., 2016, 2019a, 2019b; Possatto et al., 2011; Ramos et al., 2012; Silva et al., 2018). Within this system, contamination is enhanced during the late rainy season in the middle estuary, lower estuariy and coastal zone, coinciding with the highest availability of microplastics, when river runoff increases and flushes plastics seaward (Lima et al., 2014). Ingestion averaged 2.3 items individual $^{-1}$ in lower trophic level fishes and up to 13 items individual ${ }^{-1}$ in higher trophic level fishes (Lima et al., 2020). Although every ontogenetic phase was contaminated, a positive relationship was observed between the number of microfibres and fishes ingested by adult piscivorous fishes. In such case, piscivorous fishes seem to be more susceptible to contamination through trophic transfer, especially because $~ 50 \%$ of the fishes ingested were also contaminated (Ferreira et al., 2016; 2019a; 2019b). Therefore, despite fishes exhibiting complex spatial ranges, those depending on estuaries often spend a whole season using estuarine resources during one life phase, which may coincide with peaks in microplastic availability.

Other works mainly analysed species widely used for human consumption (fish, oysters and mussels). Researchers have warned that in Iran humans may consume up to 555 microplastic items per $300 \mathrm{~g}$ of fish week ${ }^{-1}$ (Akhbarizadeh et al., 2018). However, studies regarding the effects of plastic consumption in humans are still lacking. Some species that were used to indicate plastic pollution are not directly consumed by humans but can be preyed upon by larger fish of economic importance (Dantas et al., 2012). Such species may have ecological roles that can be crucial to an estuary and therefore should also be surveyed. Most of these studies highlighted that better assessments of aquatic animals are further necessary to improve planning regarding environmental contamination with plastics.

\section{Plastic toxicity in estuaries}

In this review, three papers investigated plastic toxicity alone in estuarine biota. Li et al. (2020b) could not see any effects on retention time, gene expression related to metal-related stress, antioxidant defence or metabolic impact in the estuarine mussel Mytilus edulis after exposure to PVC particles alone or combined with cadmium. Meanwhile, exposure to microplastics caused oxidative stress in the European seabass Dicenthrarchus labrax (Barboza et al., 2018) and neurotoxicity in the common goby
Pomatochistus microps (Miranda et al., 2019). Barboza et al. (2018) also reported that mercury was more bioconcentrated in the gills and bioaccumulated in the liver when European seabass were exposed to both metal and microplastics. On the contrary, Miranda et al. (2019) reported that the effects of simultaneous exposure of the common goby to chromium and microplastics caused an antagonistic effect (i.e. decreased neurotoxicity). Similarly, there is some evidence that the presence of microplastics decreased mortality associated with chromium toxicity in the common goby (Luís et al., 2015). These results are controversial, which indicates that different metals might interact differently with plastic particles resulting in changes in toxicity. Moreover, no paper emphasized the implications of estuarine conditions on those effects, which highlights the importance of investigating these interactions and with other types of contaminants in estuaries.

Estuaries often receive high levels of urban effluent, which carry contaminants from human activities such as pharmaceuticals, pesticides, antibiotics, personal care products and other contaminants of emerging concern (Loos et al., 2013; Pintado-Herrera et al., 2017; Celis-Hernandez et al., 2020b). Also, port and fishing activities often release chemicals to estuaries such as heavy metals from antifouling paints (AFPs) (e.g. Turner, 2010). These contaminants are toxic and some have the potential to bioaccumulate and biomagnify through the food chain (Farrell and Nelson, 2013; CelisHernandez et al., 2020a), and to interact with plastic items that can serve as a carrier for these compounds in estuaries (see "Plastics and other contaminants in estuaries").

The first paper reporting plastics in estuaries also reported polychlorinated biphenyl (PCBs) on the surface of plastic pellets (Carpenter and Smith, 1972). The authors suggested that this interaction was due to the presence of PCBs in water, as they were not used as plastic additives. PCBs are highly toxic for a number of species including humans and have been prohibited in many countries for many years (Penteado and Vaz, 2001).

Estuarine conditions can affect contaminant bioavailability. Differences in salinity/chlorinity, $\mathrm{pH}$, temperature and suspended organic material directly influence chemical speciation of metals and organic contaminants and therefore their biological affinity (Salomons and Förstner, 2012; Xu et al., 2018). If estuarine species are subjected to such contaminants, it is important to understand how this combined exposure affects them. Estuarine species are threatened in three ways: (i) by plastics and leaching of their additives; (ii) by contaminants released from wastewater treatment plants, and (iii) by local activities such as port and fishing.

\section{Biofouling on plastic in estuaries}

Once in contact with water, any hard substrate such as plastics becomes rapidly covered by particles such as ions that form a conditioning film. Following this, microorganisms such as bacteria begin a process called biofouling, that can be defined as the direct or indirect biological association to either natural or synthetic hard substrates. An initial biofilm formed by bacteria and its extracellular polymeric substances (EPS) allows other organisms such as viruses, fungi, algae, protozoans and invertebrates to colonize a surface, which can support the development of a macroscopic community called the Plastisphere (Fig. 2) (Agostini et al., 2018; Galloway et al., 2017; Zardus et al., 2008; Zettler et al., 2013).

An important implication of the plastisphere is that the fouling community can change the probability of plastic particles being ingested. This has been shown for zooplankton, where Vroom et al. (2017) identified the preference of Calanus finmarchicus for biofouled microplastics over pristine ones. They associated this behaviour with the excretion of chemical attractors by biofilms that led zooplankton to mistake plastics for food. In contrast, Kaposi 


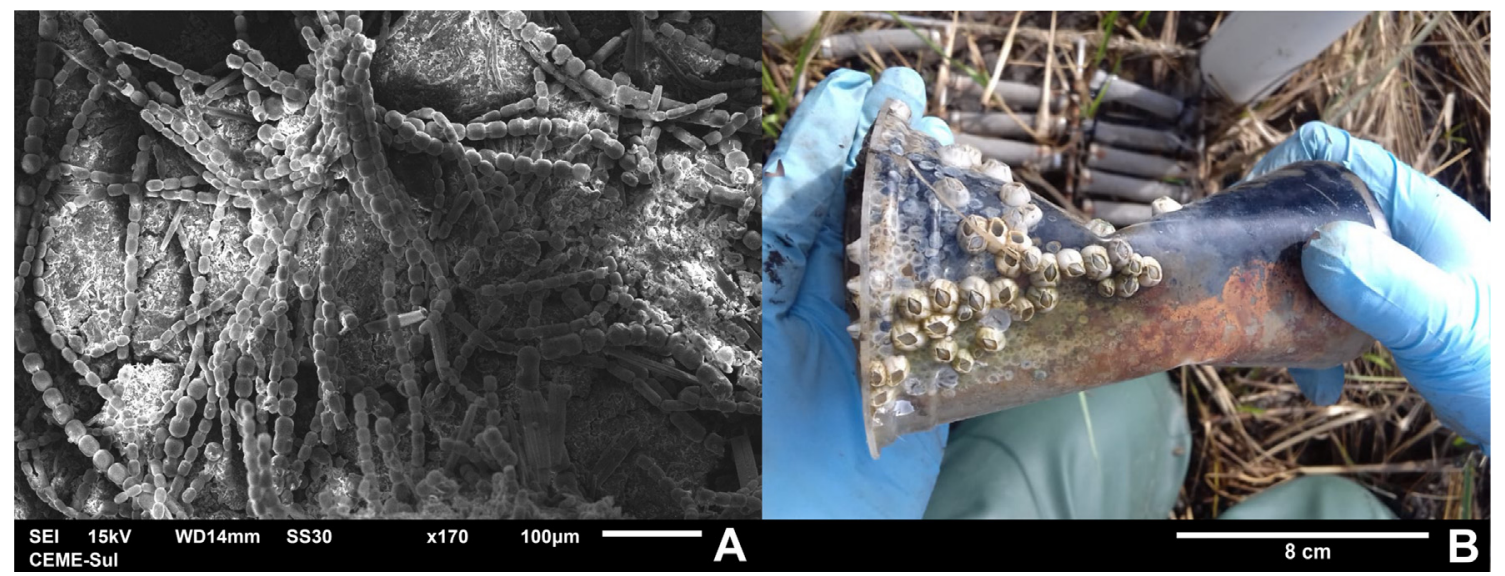

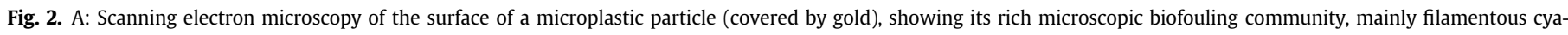

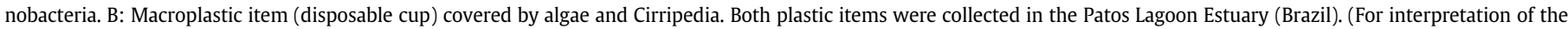
references to colour in this figure legend, the reader is referred to the Web version of this article.)

et al. (2014) showed that the percentage of Tripneustes gratilla larvae with microplastics in their stomach was higher when they were fed with non-fouled microplastics in comparison with fouled particles. They associated this with the behaviour of particle selection by larvae based on size, which was larger on fouled particles.

It has been proposed that some physical characteristics of the substrate and of the environment can interfere in biofouling (Agostini et al., 2017, 2018). Hence, this may be valid for plastic characteristics such as polymer type, size, colour and texture. In fact, Kettner et al. (2019) observed that the microbial community growing on polyethylene and polystyrene microplastics surface was different from that on wood or in the surrounding water. Environmental parameters such as $\mathrm{pH}$, salinity, temperature, nutrient availability and light can also be determining factors in microbial associations in aquatic systems (Harrison et al., 2018; Oberbeckmann et al., 2018; Rummel et al., 2017). As Oberbeckmann et al. (2018) have shown, some bacterial assemblages colonize only polyethylene and polystyrene microplastics but not wood, especially under a high salinity, low nutrient level scenario. These characteristics can vary greatly in estuaries, which affects the response of associated microbial communities.

Substrates can face alternated inundation periods caused by tides in estuaries. The fouling process can therefore be interrupted as the substrate is exposed to air, therefore the survival of the plastisphere will depend on the protection provided by its own structure (EPS) and the time it remains exposed to drought. This has been suggested to have a potential effect on the plastisphere community, but has not yet been investigated (Harrison et al., 2018).

Other factors such as plastic age (weathering) can vary in estuaries. Rivers, streams and WWTPs are often considered plastic sources (Jambeck et al., 2015), so plastics from those sources can be relatively new. In contrast, plastic residence time in the ocean is normally higher (Gewert et al., 2015), which could enhance weathering. Either way, plastic weathering will influence the biofouling process, e.g. by favouring the adherence of microorganisms to plastic (Rummel et al., 2017). Therefore, plastisphere formation and composition are likely to differ between upper and lower areas of estuaries, although this remains under investigated.

To date there are no studies investigating the effects of plastic pollution on primary producers (e.g., cyanobacteria and diatoms), but it has been shown that biofouling organisms can alter the physical properties of plastics. For example, biofouling can make plastics denser, making them sink faster (Fazey and Ryan, 2016; Long et al., 2015). Ye and Andrady (1991) exposed macroplastic items to natural conditions at the Biscayne Bay (USA) for about seven months. They observed all stages of the microfouling process and that defouling (dispersion) can occur due to chemical changes in the water as the item submerges due to increasing density, and this may be followed by a new fouling cycle.

Microorganisms that degrade polymers can also increase their buoyancy, favouring an upward movement of plastics (Rummel et al., 2017). However, biofouling can lower plastic exposure to sunlight (UV radiation) and oxygen, which slows chemical degradation processes (Kershaw et al., 2011). Either way, plastic dynamics are potentially altered by associated organisms. Most evidence shows that biofouling leads to sinking, e.g. Kaiser et al. (2017) established that the sinking velocity of biofouled PS, a negatively buoyant polymer, increased by $16 \%$ in estuarine water and $81 \%$ in marine water after 6 weeks. However, a recent study by Nguyen et al. (2020) provides different scenarios, showing that negatively buoyant polymers (PVC, polyurethane, and polyethylene terephthalate) have their sinking velocity increased when high density biofilm is attached to them, but they tend to become neutrally buoyant or even rise when aggregated with low-density biofilm. They also showed that positively buoyant polymers (PP and high-density PE) had their rising velocity enhanced when fouled by low-density biofilm but started to settle when highdensity biofilm is attached due to the effect of the increasing size of the aggregate (Nguyen et al., 2020). Therefore, they suggested that the formation of biofouling on microplastic surfaces depend on factors such as the plastic density, size, and shape but also strongly on the biofilm density (Nguyen et al., 2020). Kooi et al. (2017) developed a model for the effects of biofouling on this vertical movement of microplastics but environmental validation is still lacking.

Plastics and their plastisphere can be transported for long distances. In an estuary, this means that species living in the upper part, where freshwater predominates, might be transported to lower parts where salinity is higher. If the salinity range is high and the species is stenohaline, it might not survive the osmotic change. In contrast, euryhaline species may be able to survive a wide salinity change. Also, species transport due to biofouling of plastic items may result in the establishment of exotic species in nonnative environments. Therefore, these invasions can have a range of outcomes for the environment and for the invading species itself (Grosholz and Ruiz, 2003; Thiel and Gutow, 2005). 


\section{Plastics and other contaminants in estuaries}

Plastics can act as vectors for contaminants in the aquatic environment due to their high capacity to adsorb such components on their surface. These interactions are directly influenced by physicochemical properties of the surrounding matrix such as dissolved and particulate organic matter, $\mathrm{pH}$ and chlorinity (Salomons and Förstner, 2012; Xu et al., 2018). These properties can vary greatly in estuaries due to freshwater-saltwater mixing, dependent on local hydrodynamic conditions. Organic matter concentrations tend to be higher in the upper estuary than in the lower section as the input of organic material tends to be greater in this area (Middelburg and Herman, 2007). The chlorinity/salinity gradient is naturally accentuated in estuaries, and together with differences in biological activity they can also influence $\mathrm{pH}$ variation along these gradients (Howland et al., 2000).

The sorption capacity of polymers also depends on their properties (polymer type, colour, degradation level) and environmental properties (salinity, $\mathrm{pH}$, organic matter, presence of other sorbents) (Wang et al., 2018). In general, plastics are excellent transport agents for hydrophobic and metallic chemicals dissolved in the water, e.g. plastic polymers might have a greater sorption capacity for some persistent organic pollutants (POPs) than minerogenic sediments (Teuten et al., 2009). It can therefore be complicated to understand sorption dynamics in estuarine plastics.

Estuarine environments are often close to contamination sources such as ports, marinas and harbours, where antifouling paints (AFPs) are widely used in order to protect boats and ships from biofouling organisms (Thomas and Brooks, 2010), but their properties also act on non-target species in the environment (Soroldoni et al., 2017). A study by Onduka et al. (2013) showed toxic effects of commercial DCOIT (4,5-Dichloro-2-octyl-4-isothiazolin-3-one) in four species of algae, two crustaceans and one polychaeta, all coastal species. Therefore, AFPs act as contamination sources by releasing toxic chemicals that can potentially achieve significant concentrations in the environment and even interact with other particles such as plastics.

Another contamination source in estuaries are Wastewater Treatment Plants (WWTP), which are also a major source of microplastics (Conley et al., 2019; Xu et al., 2019) and other contaminants such as perfluoroalkyl substances (PFASs) and pharmaceutical and personal care products (PPCPs) to estuaries (Zhou et al., 2019). Some of these compounds interact with plastic particles (Wu et al., 2016), but no papers investigating this in estuaries were found in this review.

We identified seven research papers regarding plastic interaction with heavy metals and five papers with organic compounds in estuaries. Turner (2016) and Turner et al. (2015) found high concentrations of $\mathrm{Cu}, \mathrm{Pb}, \mathrm{Zn}$ and $\mathrm{Sn}$, which is an important indicator of organotin compounds banned years ago. Holmes et al. (2014) performed a field experiment by exposing beached and virgin microplastics to estuarine conditions and found that $\mathrm{pH}$ and salinity changes through the estuary alter adsorption rates of metals, and that adsorption was much higher in beached (degraded) pellets. One paper investigated the adsorption of dichloro-diphenyltrichloroethane (DDT) and phenanthrene using realistic salinity levels in order to simulate riverine, estuarine and marine environments in laboratory experiment (Bakir et al., 2014). Although concentrations of DDT and phenanthrene were slightly higher under estuarine than riverine and marine conditions, the effect of salinity on sorption kinetics was not significant. Other properties such as contaminant concentration, proximity to contamination source and plastic transport may have a stronger influence on this interaction.
Regarding biota, the capacity of microbial biofilms to absorb or even metabolize contaminants in the surrounding environment has been documented for heavy metals (Ancion et al., 2010) and organic compounds (Writer et al., 2011). If these organisms can occupy plastic surfaces, it can be expected that they will affect plastic sorption for other contaminants, but it remains unclear whether biofilms would increase or decrease plastic sorption capacity. Indeed, concern over the role of the plastisphere is increasing as it has been recently proposed that understanding how biofilms in microplastics interfere with primary production processes and interactions between organisms is largely understudied (Harrison et al., 2018).

\section{Conclusions and remarks}

Estuaries are key systems acknowledged to be systematically contaminated by plastics in both biotic and abiotic compartments. This review adds information in the so called "source-to-sea" approach in order to support future research on the estimates of plastics in rivers and estuaries. Many estuaries around the globe have not yet been investigated for plastic contamination (Fig. 1), and even worse is the case of riverine systems. Within this review, just under 100 of the more than 1200 estuaries in the world were discussed, with large gaps in the knowledge particularly concerning Africa, eastern Europe, Oceania, Central America, and western South America, that are absent from study. Despite a range of sampling methods deployed, current efforts should focus on standardizing procedures to avoid underestimations and to increase comparability in different environmental settings. Sampling designs must consider links among biological, sedimentary, and physicochemical factors to assess and predict contamination accounting for spatial, temporal, and seasonal fluctuation of environmental gradients, such as those observed in estuaries. Plastic quantities appear to be higher in river and estuarine sediments than in the water column, as expected for contaminants as a result of the mixing of water masses, accretion of bottom sediments and high sedimentary input from terrestrial sources. Thus, the water matrix is more relevant to understand episodic variation in contamination, while sediments might be more suitable for long term investigations. This review has also highlighted that semicontrolled field experiments are a valuable approach to achieve reliable results in realistically relevant scenarios and thus should be encouraged.

Plastic dynamics in estuaries are not fully understood and future studies are recommended to use the following spatial-temporal approaches: (i) water sampling at different depths and estuarine reaches to assess differences between freshwater and seawater according to the vertical stratification throughout the estuary; (ii) sediment sampling at deeper depths to account for stratigraphic variation (e.g. to $0.5 \mathrm{~m}$ ), considering sedimentation rate, sediment permeability relative to particle size, vegetation, bioturbation, human action (e.g. dredging) and extreme weather events.

Plastics interact with both lower trophic level organisms and top predators, showing a generalized exposure within estuaries but key processes remain unclear. Some questions should be addressed in future surveys: (i) how plastics bioaccumulate and are transferred between trophic levels along the river-estuary-sea continuum, and (ii) how patterns of use of estuaries during different life phases influence contamination and interaction rates. Investigation should focus on trophic/functional guilds and ontogenetic shifts in feeding behaviour, in order to consider community structures and intraspecific relationships, respectively, rather than use "species" as an ecological unit, in order to provide insights for management based on monitoring of economically and ecologically important species. 
Estuaries are often associated with highly urbanized centres, which is associated with the release of environmental contaminants such as persistent organic and metallic compounds. Both plastics and biofouling organisms can interact with these chemicals, and efforts are increasing to understand the contribution of biofouling organisms as possible vectors of contaminants onto plastic surfaces, but it remains uncertain whether these interactions increase the bioavailability of chemical contaminants, and, consequently their toxicity to organisms.

The discussion of plastic pollution mitigation and toxicity has to include synthetic fabrics, as fibres from these sources are abundant. Accordingly, fibres are commonly ingested by aquatic organisms and, thus, financial support to quickly understand how hazardous fibres are is another step to couple this information with those available for other contaminants. This is needed by organizations such as the European Environment Agency (EEA), U.S. Environmental Protection Agency (EPA), Food and Agriculture Organization of the United Nations (FAO) and the World Health Organization (WHO) to establish safe levels of microplastics in aquatic organisms for human consumption. Robust sampling is needed to predict how, where and when plastic ingestion, absorption by animal tissues and toxicity peak in the natural environment. Once these are elucidated beyond simple ingestion, efforts can be made to evaluate links with human health.

In summary, economic activities surrounding river basins, estuaries and adjacent coastal waters have been neglected concerning the risk assessments for plastic contamination, even though these are necessary to guarantee the ecological functions of these systems. Models are necessary to predict the fate of micro- and macroplastics in aquatic environments; and the inclusion of the above socio-economic aspects in modelling techniques is relevant regarding management approaches.

\section{CRediT author statement}

Pinheiro, L.M., Conceptualization, Methodology, Formal analysis, Investigation, Writing - original draft, Visualization, Project administration. Agostini, V.O., Conceptualization, Methodology, Formal analysis, Investigation, Writing - review \& editing; Lima, A.R.A., Investigation, Writing - review \& editing. Ward, R.D., Writing - review \& editing. Pinho, G.L.L., Investigation, Resources, Writing - review \& editing, Supervision, Funding acquisition.

\section{Declaration of competing interest}

The authors declare that they have no known competing financial interests or personal relationships that could have appeared to influence the work reported in this paper.

\section{Acknowledgments}

LP thanks CAPES-Brazil (CAPES/PROEX process no. 88887.34 2890/2019-00 and CAPES/PRINT process no. 88887.374104/2019 -00). VA thanks CAPES-Brazil (process no. 88887.356411/201900). GP is a CNPq research fellow (PQ2 $\mathrm{N}^{\circ} 304495 / 2019-0$ and process no. 406865/2018-3). These sponsors' support allowed the conduct of the research and the preparation of the article. AL thanks FEDER (LISBOA-01-0145-FEDER-032209) and the FCT-Portugal (PTDC/BIA-BMA/32209/2017 - SARDITEMP and UIDB/04292/2020) trough grant. The authors acknowledge the Centro de Microscopia Eletrônica do Sul (CEME-SUL/FURG) for the SEM analysis. The authors also thank Fiamma Abreu and Christian Göbel for the help with Fig. 1.

\section{Appendix A. Supplementary data}

Supplementary data to this article can be found online at https://doi.org/10.1016/j.envpol.2021.116908.

\section{References}

Acha, E.M., Mianzan, H.W., Iribarne, O., Gagliardini, D., Lasta, C., Daleo, P., 2003. The role of the Rio de la Plata bottom salinity front in accumulating debris. Mar. Pollut. Bull. 46, 197-202. https://doi.org/10.1016/S0025-326X(02)00356-9.

Adam, P., 1993. Saltmarsh Ecology. Cambridge University Press.

Agostini, V.O., Ritter, Nascimento, Do, M., Macedo, A.J., Muxagata, E., Erthal, F., 2017. What determines sclerobiont colonization on marine mollusk shells? PloS One 12, 1-27. https://doi.org/10.1371/journal.pone.0184745.

Agostini, V.O., Macedo, A.J., Muxagata, E., 2018. O papel do biofilme bacteriano no acoplamento bento-pelágico, durante o processo de bioincrustação. Rev. Lib 19, 23-41.

Akhbarizadeh, R., Moore, F., Keshavarzi, B., 2018. Investigating a probable relationship between microplastics and potentially toxic elements in fish muscles from northeast of Persian Gulf. Environ. Pollut 232, 154-163. https://doi.org/ 10.1016/j.envpol.2017.09.028.

Alder, J., 2003. Putting the coast in the "sea around Us" [WWW document]. Sea around Us Newsl. URL http://seaaroundus.org/newsletter/Issue15.pdf. http:// data.unep-wcmc.org/datasets/23.

Anbumani, S., Kakkar, P., 2018. Ecotoxicological effects of microplastics on biota: a review. Environ. Sci. Pollut. Res. 25, 14373-14396. https://doi.org/10.1007/ s11356-018-1999-X.

Ancion, P.Y., Lear, G., Lewis, G.D., 2010. Three common metal contaminants of urban runoff $(\mathrm{Zn}, \mathrm{Cu}$ and $\mathrm{Pb})$ accumulate in freshwater biofilm and modify embedded bacterial communities. Environ. Pollut. 158, 2738-2745. https://doi.org/ 10.1016/j.envpol.2010.04.013.

Anderson, Z.T., Cundy, A.B., Croudace, I.W., Warwick, P.E., Celis-Hernandez, O. Stead, J.L., 2018. A rapid method for assessing the accumulation of microplastics in the sea surface microlayer (SML) of estuarine systems. Sci. Rep. 8, 1-11. https://doi.org/10.1038/s41598-018-27612-w.

Andrade, M.C., Winemiller, K.O., Barbosa, P.S., Fortunati, A., Chelazzi, D., Cincinelli, A., Giarrizzo, T., 2019. First account of plastic pollution impacting freshwater fishes in the Amazon: ingestion of plastic debris by piranhas and other serrasalmids with diverse feeding habits. Environ. Pollut. 244, 766-773. https://doi.org/10.1016/j.envpol.2018.10.088.

Araújo, M.C., Costa, M., 2007. An analysis of the riverine contribution to the solid wastes contamination of an isolated beach at the Brazilian Northeast. Manag. Environ. Qual. An Int. J. 18, 6-12. https://doi.org/10.1108/14777830710717677.

Avio, C.G., Gorbi, S., Milan, M., Benedetti, M., Fattorini, D., D’Errico, G., Pauletto, M., Bargelloni, L., Regoli, F., 2015. Pollutants bioavailability and toxicological risk from microplastics to marine mussels. Environ. Pollut. 198, 211-222. https:// doi.org/10.1016/j.envpol.2014.12.021.

Bakir, A., Rowland, S.J., Thompson, R.C., 2014. Transport of persistent organic pollutants by microplastics in estuarine conditions. Estuar. Coast Shelf Sci. 140, 14-21. https://doi.org/10.1016/j.ecss.2014.01.004.

Barboza, L.G.A., Vieira, L.R., Branco, V., Carvalho, C., Guilhermino, L., 2018. Microplastics increase mercury bioconcentration in gills and bioaccumulation in the liver, and cause oxidative stress and damage in Dicentrarchus labrax juveniles. Sci. Rep. 8, 1-9. https://doi.org/10.1038/s41598-018-34125-z.

Bardos, P., Spencer, K.L., Ward, R.D., Maco, B.H., Cundy, A.B., 2020. Integrated and sustainable management of post-industrial coasts. Frontiers in Environmental Science 8 (86). https://doi.org/10.3389/fenvs.2020.00086.

Bellasi, A., Binda, G., Pozzi, A., Galafassi, S., Volta, P., Bettinetti, R., 2020. Microplastic contamination in freshwater environments: a review, focusing on interactions with sediments and benthic organisms. Environ 7 (4). https://doi.org/10.3390/ environments7040030.

Blettler, M.C.M., Abrial, E., Khan, F.R., Sivri, N., Espinola, L.A., 2018. Freshwater plastic pollution: recognizing research biases and identifying knowledge gaps. Water Res. 143, 416-424. https://doi.org/10.1016/j.watres.2018.06.015.

Butzeck, C., Eschenbach, A., Gröngröft, A., Hansen, K., Nolte, S., Jensen, K., 2014. Sediment deposition and accretion rates in tidal marshes are highly variable along estuarine salinity and flooding gradients. Estuar. Coast 38, 434-450. https://doi.org/10.1007/s12237-014-9848-8.

Canesi, L., Ciacci, C., Bergami, E., Monopoli, M.P., Dawson, K.A., Papa, S., Canonico, B., Corsi, I., 2015. Evidence for immunomodulation and apoptotic processes induced by cationic polystyrene nanoparticles in the hemocytes of the marine bivalve Mytilus. Mar. Environ. Res. 111, 34-40. https://doi.org/10.1016/ j.marenvres.2015.06.008.

Carpenter, E.J., Smith, K.L., 1972. Plastics on the sargasso sea surface. Science 175, 1240-1241. https://doi.org/10.1126/science.175.4027.1240.

Carr, S.A., 2017. Sources and dispersive modes of micro-fibers in the environment. Integrated Environ. Assess. Manag. 13, 466-469. https://doi.org/10.1002/ ieam.1916.

Celis-Hernandez, O., Giron-Garcia, P.M., Ontiveros-Cuadras, J., Canales-Delgadillo, J., Pérez-Ceballos, R., Ward, R.D., Acevedo-Gonzales, O., Merino-Ibarra, M., 2020a. Environmental risk of heavy metals in mangrove ecosystems: an assessment of natural vs oil and urban inputs. Sci. Total Environ. 730, 138643 https://doi.org/ 10.1016/j.scitotenv.2020.138643. 
Celis-Hernandez, O., Cundy, A., Croudace, I., Ward, R.D., Busquets, R., Wilkinson, J., 2020b. Assessing the role of the "estuarine filter" for emerging contaminants: pharmaceuticals, perfluoroalkyl compounds and plasticisers in sediment cores from two contrasting systems in the southern U.K. Water Res. 189, 116610 https://doi.org/10.1016/j.watres.2020.116610.

Cheung, P.K., Fok, L., 2017. Characterisation of plastic microbeads in facial scrubs and their estimated emissions in Mainland China. Water Res. 122, 53-61. https:// doi.org/10.1016/j.watres.2017.05.053.

Cheung, P.K., Cheung, L.T.O., Fok, L., 2016. Seasonal variation in the abundance of marine plastic debris in the estuary of a subtropical macro-scale drainage basin in South China. Sci. Total Environ. 562, 658-665. https://doi.org/10.1016/ j.scitotenv.2016.04.048.

Christensen, B.E., Trønnes, H.N., Vollan, K., Smidsrød, O., Bakke, R., 1990. Biofilm removal by low concentrations of hydrogen peroxide. Biofouling 2, 165-175. https://doi.org/10.1080/08927019009378142.

Chubarenko, I.P., Esiukova, E.E., Bagaev, A.V., Bagaeva, M.A., Grave, A.N., 2018. Threedimensional distribution of anthropogenic microparticles in the body of sandy beaches. Sci. Total Environ. 628-629, 1340-1351. https://doi.org/10.1016/ j.scitotenv.2018.02.167.

Cohen, J.H., Internicola, A.M., Mason, R.A., Kukulka, T., 2019. Observations and simulations of microplastic debris in a tide, wind, and freshwater-driven estuarine environment: the Delaware bay. Environ. Sci. Technol. 53, 14204-14211. https://doi.org/10.1021/acs.est.9b04814.

Conley, K., Clum, A., Deepe, J., Lane, H., Beckingham, B., 2019. Wastewater treatment plants as a source of microplastics to an urban estuary: removal efficiencies and loading per capita over one year. Water Res. X 3, 100030. https://doi.org/ 10.1016/J.WROA.2019.100030.

Coppock, R.L., Cole, M., Lindeque, P.K., Queirós, A.M., Galloway, T.S., 2017. A smallscale, portable method for extracting microplastics from marine sediments. Environ. Pollut 230, 829-837. https://doi.org/10.1016/j.envpol.2017.07.017.

Costa, M.F., Silva-Cavalcanti, J.S., Barbosa, C.C., Portugal, J.L., Barletta, M., 2011. Plastics buried in the inter-tidal plain of a tropical estuarine ecosystem. J. Coast Res. 165, 339-343. https://doi.org/10.2112/SI65-206.1.

Critchell, K., Lambrechts, J., 2016. Modelling accumulation of marine plastics in the coastal zone; what are the dominant physical processes? Estuar. Coast Shelf Sci. 171, 111-122. https://doi.org/10.1016/j.ecss.2016.01.036.

Crooks, N., Parker, H., Pernetta, A.P., 2019. Brain food? Trophic transfer and tissue retention of microplastics by the velvet swimming crab (Necora puber). J. Exp. Mar. Biol. Ecol. 519, 151187 https://doi.org/10.1016/j.jembe.2019.151187.

Cundy, A.B., Croudace, I.W., 1996. Sediment accretion and recent sea-level rise in the solent, southern England: inferences from radiometric and geochemical studies. Estuar. Coast Shelf Sci. 43, 449-467. https://doi.org/10.1006/ ecss.1996.0081.

Dantas, D.V., Barletta, M., da Costa, M.F., 2012. The seasonal and spatial patterns of ingestion of polyfilament nylon fragments by estuarine drums (Sciaenidae). Environ. Sci. Pollut. Res. 19, 600-606. https://doi.org/10.1007/s11356-011-05790 .

Dantas, D.V., Ribeiro, C.I.R., Frischknecht, C., de, C.A., Machado, R., Farias, E.G.G., 2019. Ingestion of plastic fragments by the Guri sea catfish Genidens genidens (Cuvier, 1829) in a subtropical coastal estuarine system. Environ. Sci. Pollut. Res. 26, 8344-8351. https://doi.org/10.1007/s11356-019-04244-9.

Day, J.W., Crump, B.C., Kemp, W.M., Yáñes-arancibia, A. (Eds.), 2013. Estuarine Ecology, Second. ed. Wiley-Blackwell.

De Villiers, S., 2019. Microfibre pollution hotspots in river sediments adjacent to South Africa's coastline. WaterSA 45, 97-102. https://doi.org/10.4314/ wsa.v45i1.11.

Dris, R., Gasperi, J., Rocher, V., Saad, M., Renault, N., Tassin, B., 2015. Microplastic contamination in an urban area: a case study in Greater Paris. Environ. Chem. 12 (592) https://doi.org/10.1071/EN14167.

Erni-cassola, G., Zadjelovic, V., Gibson, M.I., Christie-oleza, J.A., 2019. Distribution of plastic polymer types in the marine environment: a meta- analysis. J. Hazard Mater. 369, 691-698. https://doi.org/10.1016/j.jhazmat.2019.02.067.

Farrell, P., Nelson, K., 2013. Trophic level transfer of microplastic: Mytilus edulis (L.) to Carcinus maenas (L.). Environ. Pollut. 177, 1-3. https://doi.org/10.1016/ j.envpol.2013.01.046.

Fazey, F.M.C., Ryan, P.G., 2016. Biofouling on buoyant marine plastics: an experimental study into the effect of size on surface longevity. Environ. Pollut. 210, 354-360. https://doi.org/10.1016/j.envpol.2016.01.026.

Feagin, R.A., Lozada-Bernard, S.M., Ravens, T.M., Möller, I., Yeager, K.M., Baird, A.H., 2009. Does vegetation prevent wave erosion of salt marsh edges? Proc. Natl. Acad. Sci. Unit. States Am. 106, 10109-10113. https://doi.org/10.1073/ pnas.0901297106.

Ferreira, G.V.B., Barletta, M., Lima, A.R.A., Dantas, D.V., Justino, A.K.S., Costa, M.F., 2016. Plastic debris contamination in the life cycle of Acoupa weakfish (Cynoscion acoupa) in a tropical estuary. ICES J. Mar. Sci. J. du Cons 73, 2695-2707. https://doi.org/10.1093/icesjms/fsw108.

Ferreira, G.V.B., Barletta, M., Lima, A.R.A., Morley, S.A., Costa, M.F., 2019a. Dynamics of marine debris ingestion by profitable fishes along the estuarine ecocline. Sci. Rep. 9, 1-12. https://doi.org/10.1038/s41598-019-49992-3.

Ferreira, G.V.B., Barletta, M., Lima, A.R.A., 2019b. Use of estuarine resources by top predator fishes. How do ecological patterns affect rates of contamination by microplastics? Sci. Total Environ. 655, 292-304. https://doi.org/10.1016/ j.scitotenv.2018.11.229.

Fok, L., Cheung, P.K., 2015. Hong Kong at the Pearl River Estuary: a hotspot of microplastic pollution. Mar. Pollut. Bull. 99, 112-118. https://doi.org/10.1016/ j.marpolbul.2015.07.050

Fok, L., Cheung, P.K., Tang, G., Li, W.C., 2017. Size distribution of stranded small plastic debris on the coast of Guangdong, South China. Environ. Pollut 220, 407-412. https://doi.org/10.1016/j.envpol.2016.09.079.

Frère, L., Paul-Pont, I., Rinnert, E., Petton, S., Jaffré, J., Bihannic, I., Soudant, P., Lambert, C., Huvet, A., 2017. Influence of environmental and anthropogenic factors on the composition, concentration and spatial distribution of microplastics: a case study of the Bay of Brest (Brittany, France). Environ. Pollut 225, 211-222. https://doi.org/10.1016/j.envpol.2017.03.023.

Frias, J.P.G.L., 2018. Standardised protocol for monitoring microplastics in sediments. https://doi.org/10.13140/RG.2.2.36256.89601.

Galgani, F., Hanke, G., Werner, S., Oosterban, L., Nilsson, P., Fleet, D., Kinsey, S., Thompson, R.C., Franeker, J.A., Vlachogianni, T., Scoullos, M., Veiga, J.M., Palatinus, A., Matiddi, M., Maes, T., Korpinen, S., Budziak, A., Leslie, H., Gago, J., Liebezeit, G., 2013. Guidance on Monitoring of Marine Litter in European Seas. Publications Office of the European Union, Luxembourg. https://doi.org/ $10.2788 / 99475$.

Galloway, T.S., Cole, M., Lewis, C., 2017. Interactions of microplastic debris throughout the marine ecosystem. Nat. Ecol. Evol. 1, 1-8. https://doi.org/ 10.1038/s41559-017-0116.

Gebhardt, C., Forster, S., 2018. Size-selective feeding of Arenicola marina promotes long-term burial of microplastic particles in marine sediments. Environ. Pollut. 242, 1777-1786. https://doi.org/10.1016/j.envpol.2018.07.090.

Gewert, B., Plassmann, M.M., MacLeod, M., 2015. Pathways for degradation of plastic polymers floating in the marine environment. Environ. Sci. Process. Impacts 17, 1513-1521. https://doi.org/10.1039/c5em00207a.

Gies, E.A., LeNoble, J.L., Noël, M., Etemadifar, A., Bishay, F., Hall, E.R., Ross, P.S., 2018 Retention of microplastics in a major secondary wastewater treatment plant in Vancouver, Canada. Mar. Pollut. Bull. 133, 553-561. https://doi.org/10.1016/ j.marpolbul.2018.06.006.

Green, D.S., Boots, B., Sigwart, J., Jiang, S., Rocha, C., 2016. Effects of conventional and biodegradable microplastics on a marine ecosystem engineer (Arenicola marina) and sediment nutrient cycling. Environ. Pollut. 208, 426-434. https://doi.org/ 10.1016/j.envpol.2015.10.010.

Griffiths, J.R., Kadin, M., Nascimento, F.J.A., Tamelander, T., Törnroos, A., Bonaglia, S., Bonsdorff, E., Brüchert, V., Gårdmark, A., Järnström, M., Kotta, J., Lindegren, M., Nordström, M.C., Norkko, A., Olsson, J., Weigel, B., Žydelis, R., Blenckner, T., Niiranen, S., Winder, M., 2017. The importance of benthic-pelagic coupling for marine ecosystem functioning in a changing world. Glob. Chang. Biol. 23, 2179-2196. https://doi.org/10.1111/gcb.13642.

Grosholz, E.D., Ruiz, G.M., 2003. Biological invasions drive size increases in marine and estuarine invertebrates. Ecol. Lett. 6, 700-705. https://doi.org/10.1046/ j.1461-0248.2003.00495.x.

Guebert-Bartholo, F.M., Barletta, M., Costa, M.F., Monteiro-Filho, E.L.A., 2011. Using gut contents to assess foraging patterns of juvenile green turtles Chelonia mydas in the Paranaguá Estuary, Brazil. Endanger. Species Res. 13, 131-143. https:// doi.org/10.3354/esr00320.

Hahladakis, J.N., Velis, C.A., Weber, R., Iacovidou, E., Purnell, P., 2018. An overview of chemical additives present in plastics: migration, release, fate and environmental impact during their use, disposal and recycling. J. Hazard Mater. 344, 179-199. https://doi.org/10.1016/j.jhazmat.2017.10.014.

Hall, N.M., Berry, K.L.E., Rintoul, L., Hoogenboom, M.O., 2015. Microplastic ingestion by scleractinian corals. Mar. Biol. 162, 725-732. https://doi.org/10.1007/s00227015-2619-7.

Harrison, J.P., Schratzberger, M., Sapp, M., Osborn, A.M., 2014. Rapid bacterial colonization of low-density polyethylene microplastics in coastal sediment microcosms. BMC Microbiol. 14, 1-15. https://doi.org/10.1186/s12866-0140232-4.

Harrison, J.P., Hoellein, T.J., Sapp, M., Tagg, A.S., Ju-Nam, Y., Ojeda, J.J., 2018. Microplastic-associated biofilms: a comparison of freshwater and marine environments. pp. 181-201. https://doi.org/10.1007/978-3-319-61615-5_9.

Holmes, L.A., Turner, A., Thompson, R.C., 2014. Interactions between trace metals and plastic production pellets under estuarine conditions. Mar. Chem. 167, 25-32. https://doi.org/10.1016/j.marchem.2014.06.001.

Horton, A.A., Svendsen, C., Williams, R.J., Spurgeon, D.J., Lahive, E., 2017. Large microplastic particles in sediments of tributaries of the River Thames, UK abundance, sources and methods for effective quantification. Mar. Pollut. Bull. 114, 218-226. https://doi.org/10.1016/j.marpolbul.2016.09.004.

Howland, R.J.M., Tappin, A.D., Uncles, R.J., Plummer, D.H., Bloomer, N.J., 2000. Distributions and seasonal variability of $\mathrm{pH}$ and alkalinity in the Tweed Estuary, UK. Sci. Total Environ. 251-252, 125-138. https://doi.org/10.1016/S00489697(00)00406-X.

Iribarne, O., Botto, F., Martinetto, P., Gutierrez, J.L., 2000. The role of burrows of the SW Atlantic intertidal crab Chasmagnathus granulata in trapping debris. Mar. Pollut. Bull. 40, 1057-1062. https://doi.org/10.1016/S0025-326X(00)00058-8.

Isobe, A., Buenaventura, N.T., Chastain, S., Chavanich, S., Cózar, A., DeLorenzo, M., Hagmann, P., Hinata, H., Kozlovskii, N., Lusher, A.L., Martí, E., Michida, Y., Mu, J., Ohno, M., Potter, G., Ross, P.S., Sagawa, N., Shim, W.J., Song, Y.K., Takada, H., Tokai, T., Torii, T., Uchida, K., Vassillenko, K., Viyakarn, V., Zhang, W., 2019. An interlaboratory comparison exercise for the determination of microplastics in standard sample bottles. Mar. Pollut. Bull. 146, 831-837. https://doi.org/10.1016/ j.marpolbul.2019.07.033.

Ivar do Sul, J.A., Costa, M.F., 2013. Plastic pollution risks in an estuarine conservation unit. J. Coast Res. 65, 48-53. https://doi.org/10.2112/SI65-009.1.

Ivar do Sul, J.A., Costa, M.F., Silva-Cavalcanti, J.S., Araújo, M.C.B., 2014. Plastic debris 
retention and exportation by a mangrove forest patch. Mar. Pollut. Bull. 78, 252-257. https://doi.org/10.1016/j.marpolbul.2013.11.011.

Jambeck, J.R., Geyer, R., Wilcox, C., Siegler, T.R., Perryman, M., Andrady, A., Narayan, R., Law, K.L., 2015. Plastic waste inputs from land into the ocean. Science 347, 768-771. https://doi.org/10.1126/science.1260352.

Jensen, J.L., Schjønning, P., Watts, C.W., Christensen, B.T., Munkholm, L.J., 2017. Soil texture analysis revisited: removal of organic matter matters more than ever. PLoS One 12, e0178039. https://doi.org/10.1371/journal.pone.0178039.

Kaiser, D., Kowalski, N., Waniek, J.J., 2017. Effects of biofouling on the sinking behavior of microplastics. Environ. Res. Lett. 12 https://doi.org/10.1088/17489326/aa8e8b.

Kaposi, K.L., Mos, B., Kelaher, B.P., Dworjanyn, S.A., 2014. Ingestion of microplastic has limited impact on a marine larva. Environ. Sci. Technol. 48, 1638-1645. https://doi.org/10.1021/es404295e.

Kartar, S., Abou-Seedo, F., Sainsbury, M., 1976. Polystyrene spherules in the Severn Estuary - a progress report. Mar. Pollut. Bull. 7 (52) https://doi.org/10.1016/ 0025-326X(76)90092-8.

Kazour, M., Jemaa, S., El Rakwe, M., Duflos, G., Hermabassiere, L., Dehaut, A., Le Bihanic, F., Cachot, J., Cornille, V., Rabhi, K., Khalaf, G., Amara, R., 2020. Juvenile fish caging as a tool for assessing microplastics contamination in estuarine fish nursery grounds. Environ. Sci. Pollut. Res. 27, 3548-3559. https://doi.org/ 10.1007/s11356-018-3345-8.

Kershaw, P., Katsuhiko, S., Leemseth, J., Woodring, D., 2011. Plastic debris in the ocean, UNEP yearbook: emerging issues in our environment.

Kettner, M.T., Oberbeckmann, S., Labrenz, M., Grossart, H.-P., 2019. The Eukaryotic life on microplastics in brackish ecosystems. Front. Microbiol. 10 https://doi.org/ 10.3389/fmicb.2019.00538.

Klein, S., Worch, E., Knepper, T.P., 2015. Occurrence and spatial distribution of microplastics in river shore sediments of the rhine-main area in Germany. Environ. Sci. Technol. 49, 6070-6076. https://doi.org/10.1021/acs.est.5b00492.

Koelmans, A.A., Besseling, E., Shim, W.J., 2015. Nanoplastics in the aquatic environment. critical review. In: Bergmann, M., Gutow, L., Klages, M. (Eds.), Marine Anthropogenic Litter. Springer International Publishing, Cham, pp. 325-340. https://doi.org/10.1007/978-3-319-16510-3 12.

Kooi, M., Van Nes, E.H., Scheffer, M., Koelmans, A.A., 2017. Ups and downs in the ocean: effects of biofouling on vertical transport of microplastics. Environ. Sci. Technol. 51, 7963-7971. https://doi.org/10.1021/acs.est.6b04702.

Krelling, A.P., Turra, A., 2019. Influence of oceanographic and meteorological events on the quantity and quality of marine debris along an estuarine gradient. Mar. Pollut. Bull. 139, 282-298. https://doi.org/10.1016/j.marpolbul.2018.12.049.

Krelling, A.P., Souza, M.M., Williams, A.T., Turra, A., 2017. Transboundary movement of marine litter in an estuarine gradient: evaluating sources and sinks using hydrodynamic modelling and ground truthing estimates. Mar. Pollut. Bull. 119, 48-63. https://doi.org/10.1016/j.marpolbul.2017.03.034.

Lacerda, L.D., Ward, R.D., Godoy, M.D.P., Meireles, A.J.A., Borges, R. and Ferreira, A.C. (in press). 20-years cumulative impact from shrimp farming on mangroves of NE Brazil. Frontiers in Forests \& Global Change.

Lebreton, L.C.M., Zwet, J., Damsteeg, J., Slat, B., Andrady, A., Reisser, J., 2017. River plastic emissions to the world's oceans. Nat. Commun. 8, 1-10. https://doi.org/ 10.1038/ncomms15611.

Lechner, A., Keckeis, H., Lumesberger-Loisl, F., Zens, B., Krusch, R., Tritthart, M., Glas, M., Schludermann, E., 2014. The Danube so colourful: a potpourri of plastic litter outnumbers fish larvae in Europe's second largest river. Environ. Pollut 188, 177-181. https://doi.org/10.1016/j.envpol.2014.02.006.

Leslie, H.A., Brandsma, S.H., Velzen, M.J.M., Van Vethaak, A.D., 2017. Microplastics en route: field measurements in the Dutch river delta and Amsterdam canals, wastewater treatment plants, North Sea sediments and biota. Environ. Int. 101, 133-142. https://doi.org/10.1016/j.envint.2017.01.018.

Li, H.X., Ma, L.S., Lin, L., Ni, Z.X., Xu, X.R., Shi, H.H., Yan, Y., Zheng, G.M., Rittschof, D., 2018a. Microplastics in oysters Saccostrea cucullata along the Pearl River estuary, China. Environ. Pollut 236, 619-625. https://doi.org/10.1016/ j.envpol.2018.01.083.

Li, J., Liu, H., Paul Chen, J., 2018b. Microplastics in freshwater systems: a review on occurrence, environmental effects, and methods for microplastics detection. Water Res. 137, 362-374. https://doi.org/10.1016/j.watres.2017.12.056.

Li, J., Huang, W., Xu, Y., Jin, A., Zhang, D., Zhang, C., 2020a. Microplastics in sediment cores as indicators of temporal trends in microplastic pollution in Andong salt marsh, Hangzhou Bay, China. Reg. Stud. Mar. Sci. 35, 101149 https://doi.org/ 10.1016/j.rsma.2020.101149.

Li, J., Chapman, E.C., Shi, H., Rotchell, J.M., 2020b. PVC does not influence cadmium uptake or effects in the mussel (Mytilus edulis). Bull. Environ. Contam. Toxicol 104, 315-320. https://doi.org/10.1007/s00128-020-02789-x.

Lima, A.R.A., Costa, M.F., Barletta, M., 2014. Distribution patterns of microplastics within the plankton of a tropical estuary. Environ. Res. 132, 146-155. https:// doi.org/10.1016/j.envres.2014.03.031.

Lima, A.R.A., Silva, M.D., Possato, F.E., Ferreira, G.V.B., Krelling, A.P., 2020. Plastic contamination in Brazilian freshwater and coastal environments: a source-tosea transboundary approach. In: Stock, F., Reifferscheid, G., Brennholt, N., Kostianaia, E. (Eds.), The Handbook of Environmental Chemistry. Springer, Berlin, Heidelberg. https://doi.org/10.1007/698_2020_514.

Lima, A.R.A., Ferreira, G.V.B., Barrows, A.P.W., Christiansen, K.S., Treinish, G., Toshack, M.C., 2021. Global patterns for the spatial distribution of floating microfibers: arctic Ocean as a potential accumulation zone. J. Hazard Mater. 403, 123796 https://doi.org/10.1016/j.jhazmat.2020.123796.

Lobelle, D., Cunliffe, M., 2011. Early microbial biofilm formation on marine plastic debris. Mar. Pollut. Bull. 62, 197-200. https://doi.org/10.1016/ j.marpolbul.2010.10.013.

Long, M., Moriceau, B., Gallinari, M., Lambert, C., Huvet, A., Raffray, J., Soudant, P., 2015. Interactions between microplastics and phytoplankton aggregates: impact on their respective fates. Mar. Chem. 175, 39-46. https://doi.org/ 10.1016/j.marchem.2015.04.003.

Loos, R., Carvalho, R., António, D.C., Comero, S., Locoro, G., Tavazzi, S., Paracchini, B., Ghiani, M., Lettieri, T., Blaha, L., Jarosova, B., Voorspoels, S., Servaes, K., Haglund, P., Fick, J., Lindberg, R.H., Schwesig, D., Gawlik, B.M., 2013. EU-wide monitoring survey on emerging polar organic contaminants in wastewater treatment plant effluents. Water Res. 47, 6475-6487. https://doi.org/10.1016/ j.watres.2013.08.024.

Lourenço, P.M., Serra-Gonçalves, C., Ferreira, J.L., Catry, T., Granadeiro, J.P., 2017. Plastic and other microfibers in sediments, macroinvertebrates and shorebirds from three intertidal wetlands of southern Europe and west Africa. Environ. Pollut 231, 123-133. https://doi.org/10.1016/j.envpol.2017.07.103.

Luís, L.G., Ferreira, P., Fonte, E., Oliveira, M., Guilhermino, L., 2015. Does the presence of microplastics influence the acute toxicity of chromium(VI) to early juveniles of the common goby (Pomatoschistus microps)? A study with juveniles from two wild estuarine populations. Aquat. Toxicol 164, 163-174. https://doi.org/ 10.1016/j.aquatox.2015.04.018.

Maccready, P., Geyer, W.R., Burchard, H., 2018. Estuarine exchange flow is related to mixing through the salinity variance budget. J. Phys. Oceanogr. 48, 1375-1384. https://doi.org/10.1175/JPO-D-17-0266.1.

Mai, L., Sun, X., Xia, L., Bao, L., Liu, L., Zeng, E.Y., 2020. Global riverine plastic outflows. Environ. Sci. Technol. 54, 10049-10056. https://doi.org/10.1021/ acs.est.0c02273.

Martinetto, P., Montemayor, D.I., Alberti, J., Costa, C.S.B., Iribarne, O., 2016. Crab bioturbation and herbivory may account for variability in carbon sequestration and stocks in South west atlantic salt marshes. Front. Mar. Sci. 3 https://doi.org/ 10.3389/fmars.2016.00122.

Mason, S.A., Garneau, D., Sutton, R., Chu, Y., Ehmann, K., Barnes, J., Fink, P., Papazissimos, D., Rogers, D.L., 2016. Microplastic pollution is widely detected in US municipal wastewater treatment plant effluent. Environ. Pollut. 218, 1045-1054. https://doi.org/10.1016/j.envpol.2016.08.056.

Mathalon, A., Hill, P., 2014. Microplastic fibers in the intertidal ecosystem surrounding halifax harbor, Nova scotia. Mar. Pollut. Bull. 81, 69-79. https:// doi.org/10.1016/j.marpolbul.2014.02.018.

Mattsson, K., Jocic, S., Doverbratt, I., Hansson, L.-A., 2018. Nanoplastics in the aquatic environment. In: Microplastic Contamination in Aquatic Environments. Elsevier, pp. 379-399. https://doi.org/10.1016/b978-0-12-813747-5.00013-8.

Middelburg, Herman, 2007. Organic matter processing in tidal estuaries. Marine Chemistry 106 (1-2), 127-147. https://doi.org/10.1016/j.marchem.2006.02.007.

Miranda, T., Vieira, L.R., Guilhermino, L., 2019. Neurotoxicity, behavior, and lethal effects of cadmium, microplastics, and their mixtures on Pomatoschistus microps juveniles from two wild populations exposed under laboratory conditions-implications to environmental and human risk assessment. Int. J. Environ. Res. Public Health 16 (16), 2857. https://doi.org/10.3390/ijerph16162857.

Misic, C., Harriague, A.C., Ferrari, M., 2019. Hydrodynamic forcing and sand permeability influence the distribution of anthropogenic microparticles in beach sediment. Estuar. Coast Shelf Sci. 230, 106429 https://doi.org/10.1016/ j.ecss.2019.106429.

Morritt, D., Stefanoudis, P.V., Pearce, D., Crimmen, O.A., Clark, P.F., 2014. Plastic in the Thames: a river runs through it. Mar. Pollut. Bull. 78, 196-200. https:// doi.org/10.1016/j.marpolbul.2013.10.035.

Murray, F., Cowie, P.R., 2011. Plastic contamination in the decapod crustacean Nephrops norvegicus (Linnaeus, 1758). Mar. Pollut. Bull. 62, 1207-1217. https:// doi.org/10.1016/j.marpolbul.2011.03.032.

Naidoo, T., Glassom, D., Smit, A.J., 2015. Plastic pollution in five urban estuaries of KwaZulu-Natal, South Africa. Mar. Pollut. Bull. 101, 473-480. https://doi.org/ 10.1016/j.marpolbul.2015.09.044.

Näkki, P., Setälä, O., Lehtiniemi, M., 2017. Bioturbation transports secondary microplastics to deeper layers in soft marine sediments of the northern Baltic Sea. Mar. Pollut. Bull. 119, 255-261. https://doi.org/10.1016/ j.marpolbul.2017.03.065.

Nelms, S.E., Eyles, L., Godley, B.J., Richardson, P.B., Selley, H., Solandt, J.L., Witt, M.J., 2020. Investigating the distribution and regional occurrence of anthropogenic litter in English marine protected areas using 25 years of citizen-science beach clean data. Environ. Pollut. 263, 114365 https://doi.org/10.1016/ j.envpol.2020.114365.

Nguyen, T.H., Tang, F.H.M., Maggi, F., 2020. Sinking of microbial-associated microplastics in natural waters. PloS One 15, 1-20. https://doi.org/10.1371/ journal.pone.0228209.

Niencheski, L.F., Windom, H.L., 1994. Nutrient flux and budget in Patos Lagoon estuary. Sci. Total Environ. 149, 53-60. https://doi.org/10.1016/0048-9697(94) 90004-3.

Oberbeckmann, S., Kreikemeyer, B., Labrenz, M., 2018. Environmental factors support the formation of specific bacterial assemblages on microplastics. Front. Microbiol. 8, 1-12. https://doi.org/10.3389/fmicb.2017.02709.

Ockelford, A., Cundy, A., Ebdon, J.E., 2020. Storm response of fluvial sedimentary microplastics. Sci. Rep. 10 (1865) https://doi.org/10.1038/s41598-020-58765-2.

Onduka, T., Ojima, D., Ito, M., Ito, K., Mochida, K., Fujii, K., 2013. Toxicity of the antifouling biocide Sea-Nine 211 to marine algae, crustacea, and a polychaete. Fish. Sci. 79, 999-1006. https://doi.org/10.1007/s12562-013-0678-6.

O’Donovan, S., Mestre, N.C., Abel, S., Fonseca, T.G., Carteny, C.C., Cormier, B., 
Keiter, S.H., Bebianno, M.J., 2018. Ecotoxicological effects of chemical contaminants adsorbed to microplastics in the clam Scrobicularia plana. Front. Mar. Sci. 5, 1-15. https://doi.org/10.3389/fmars.2018.00143.

Pazos, R.S., Maiztegui, T., Colautti, D.C., Paracampo, A.H., Gómez, N., 2017. Microplastics in gut contents of coastal freshwater fish from Río de la Plata estuary. Mar. Pollut. Bull. 122, 85-90. https://doi.org/10.1016/j.marpolbul.2017.06.007.

Penteado, J.C.P., Vaz, J.M., 2001. O legado das bifenilas policloradas (PCBs). Quim. Nova 24, 390-398. https://doi.org/10.1590/S0100-40422001000300016.

Pintado-Herrera, M.G., Wang, C., Lu, J., Chang, Y.-P., Chen, W., Li, X., Lara-Martín, P.A., 2017. Distribution, mass inventories, and ecological risk assessment of legacy and emerging contaminants in sediments from the Pearl River Estuary in China. J. Hazard Mater. 323, 128-138. https://doi.org/10.1016/j.jhazmat.2016.02.046.

Possatto, F.E., Barletta, M., Costa, M.F., Ivar do Sul, J.A., Dantas, D.V., 2011. Plastic debris ingestion by marine catfish: an unexpected fisheries impact. Mar. Pollut. Bull. 62, 1098-1102. https://doi.org/10.1016/j.marpolbul.2011.01.036.

Ramos, J.A.A., Barletta, M., Costa, M.F., 2012. Ingestion of nylon threads by gerreidae while using a tropical estuary as foraging grounds. Aquat. Biol. 17, 29-34. https://doi.org/10.3354/ab00461.

Rebolledo, Bravo, Van Franeker, J.A., Jansen, O.E., Brasseur, S.M.J.M., 2013. Plastic ingestion by harbour seals (Phoca vitulina) in The Netherlands. Mar. Pollut. Bull. 67, 200-202. https://doi.org/10.1016/j.marpolbul.2012.11.035.

Revel, M., Yakovenko, N., Caley, T., Guillet, C., Châtel, A., Mouneyrac, C., 2020. Accumulation and immunotoxicity of microplastics in the estuarine worm Hediste diversicolor in environmentally relevant conditions of exposure. Environ. Sci. Pollut. Res. 27, 3574-3583. https://doi.org/10.1007/s11356-018-3497-6.

Richardson, N., Gordon, A.K., Muller, W.J., Whitfield, A.K., 2011. A weight-of-evidence approach to determine estuarine fish health using indicators from multiple levels of biological organization. Aquat. Conserv. Mar. Freshw. Ecosyst 21, 423-432. https://doi.org/10.1002/aqc.1207.

Rist, S., Baun, A., Hartmann, N.B., 2017. Ingestion of micro- and nanoplastics in Daphnia magna - quantification of body burdens and assessment of feeding rates and reproduction. Environ. Pollut. 228, 398-407. https://doi.org/10.1016/ j.envpol.2017.05.048.

Rummel, C.D., Jahnke, A., Gorokhova, E., Kühnel, D., Schmitt-Jansen, M., 2017. Impacts of biofilm formation on the fate and potential effects of microplastic in the aquatic environment. Environ. Sci. Technol. Lett. 4, 258-267. https://doi.org/ 10.1021/acs.estlett.7b00164.

Sadri, S.S., Thompson, R.C., 2014. On the quantity and composition of floating plastic debris entering and leaving the Tamar Estuary, Southwest England. Mar. Pollut. Bull. 81, 55-60. https://doi.org/10.1016/j.marpolbul.2014.02.020.

Salomons, W., Förstner, U., 2012. Metals in the hydrocycle. Springer science \& business media.

Santana, M.F.M., Moreira, F.T., Turra, A., 2017. Trophic transference of microplastics under a low exposure scenario: insights on the likelihood of particle cascading along marine food-webs. Mar. Pollut. Bull. 121, 154-159. https://doi.org/ 10.1016/j.marpolbul.2017.05.061.

Schubel, J.R., 1982. Estuarine sedimentation. In: Beaches and Coastal Geology. Kluwer Academic Publishers, Dordrecht, pp. 400-402. https://doi.org/10.1007/ 0-387-30843-1_177.

Seeliger, U., Odebrecht, C., Castello, J.P., 1998. Os ecossistemas costeiro e marinho do extremo sul do Brasil, Ecoscientia. Ecoscientia, Rio Grande.

Sembiring, E., Fareza, A.A., Suendo, V., Reza, M., 2020. The presence of microplastics in water, sediment, and milkfish (Chanos chanos) at the downstream area of Citarum River, Indonesia. Water. Air. Soil Pollut 231. https://doi.org/10.1007/ s11270-020-04710-y.

Setälä, O., Magnusson, K., Lehtiniemi, M., Norén, F., 2016. Distribution and abundance of surface water microlitter in the Baltic Sea: a comparison of two sampling methods. Mar. Pollut. Bull. 110 (1), 177-183. https://doi.org/10.1016/ j.marpolbul.2016.06.065.

Silva, J.D.B., Barletta, M., Lima, A.R.A., Ferreira, G.V.B., 2018. Use of resources and microplastic contamination throughout the life cycle of grunts (Haemulidae) in a tropical estuary. Environ. Pollut. 242, 1010-1021. https://doi.org/10.1016/ j.envpol.2018.07.038.

Soroldoni, S., Abreu, F., Castro, Ítalo B., Duarte, F.A., Pinho, G.L.L., 2017. Are antifouling paint particles a continuous source of toxic chemicals to the marine environment? J. Hazard Mater. 330, 76-82. https://doi.org/10.1016/ j.jhazmat.2017.02.001.

Stolte, A., Forster, S., Gerdts, G., Schubert, H., 2015. Microplastic concentrations in beach sediments along the German Baltic coast. Mar. Pollut. Bull. 99, 216-229. https://doi.org/10.1016/j.marpolbul.2015.07.022.

Strungaru, S.A., Jijie, R., Nicoara, M., Plavan, G., Faggio, C., 2019. Micro- (nano) plastics in freshwater ecosystems: abundance, toxicological impact and quantification methodology. TrAC Trends Anal. Chem. (Reference Ed.) 110, 116-128. https://doi.org/10.1016/j.trac.2018.10.025.

Talley, T.S., Venuti, N., Whelan, R., 2020. Natural history matters: plastics in estuarine fish and sediments at the mouth of an urban watershed. PloS One 15 , 1-19. https://doi.org/10.1371/journal.pone.0229777.

Teasdale, P.A., Collins, P.E.F., Firth, C.R., Cundy, A.B., 2011. Recent estuarine sedimentation rates from shallow inter-tidal environments in western Scotland: implications for future sea-level trends and coastal wetland development. Quat. Sci. Rev. 30, 109-129. https://doi.org/10.1016/j.quascirev.2010.08.002.

Teuchies, J., Vandenbruwaene, W., Carpentier, R., Bervoets, L., Temmerman, S., Wang, C., Maris, T., Cox, T.J.S., Braeckel, A., Van Meire, P., 2013. Estuaries as filters: the role of tidal marshes in trace metal removal $8,1-11$. https://doi.org/ 10.1371 /journal.pone.0070381.
Teuten, E.L., Saquing, J.M., Knappe, D.R.U., Rowland, S.J., Barlaz, M.A., Jonsson, S., Bjo, A., Thompson, R.C., Galloway, T.S., Yamashita, R., Ochi, D., Watanuki, Y., Moore, C., Viet, P.H., Tana, T.S., 2009. Transport and release of chemicals from plastics to the environment and to wildlife 2027-2045. https://doi.org/10.1098/ rstb.2008.0284.

Thiel, M., Gutow, L., 2005. The ecology of rafting in the marine environment. II. The rafting organisms and community. Oceanography and Marine Biology. CRC Press, pp. 289-428 https://doi.org/10013/epic.22063.

Thomas, K.V., Brooks, S., 2010. The environmental fate and effects of antifouling paint biocides. Biofouling 26, 73-88. https://doi.org/10.1080/ 08927010903216564.

Turner, A., 2010. Marine pollution from antifouling paint particles. Mar. Pollut. Bull. 60, 159-171. https://doi.org/10.1016/j.marpolbul.2009.12.004.

Turner, A., 2016. Heavy metals, metalloids and other hazardous elements in marine plastic litter. Mar. Pollut. Bull. 111, 136-142. https://doi.org/10.1016/ j.marpolbul.2016.07.020.

Turner, A., Comber, S., Rees, A.B., Gkiokas, D., Solman, K., 2015. Metals in boat paint fragments from slipways, repair facilities and abandoned vessels: an evaluation using field portable XRF. Talanta 131, 372-378. https://doi.org/10.1016/ j.talanta.2014.08.012.

Turra, A., Manzano, B., Jasa, R., Dias, S., Mahiques, M.M., Barbosa, L., Balthazarsilva, D., Moreira, F.T., 2014. Three-dimensional distribution of plastic pellets in sandy beaches: shifting paradigms 4. https://doi.org/10.1038/srep04435.

Unice, K.M., Weeber, M.P., Abramson, M.M., Reid, R.C.D., van Gils, J.A.G., Markus, A.A., Vethaak, A.D., Panko, J.M., 2019. Characterizing export of landbased microplastics to the estuary - Part I: application of integrated geospatial microplastic transport models to assess tire and road wear particles in the Seine watershed. Sci. Total Environ. 646, 1639-1649. https://doi.org/ 10.1016/j.scitotenv.2018.07.368.

Van Cauwenberghe, L., Vanreusel, A., Mees, J., Janssen, C.R., 2013. Microplastic pollution in deep-sea sediments. Environ. Pollut. 182, 495-499. https://doi.org/ 10.1016/j.envpol.2013.08.013.

Vermeiren, P., Muñoz, C.C., Ikejima, K., 2016. Sources and sinks of plastic debris in estuaries: a conceptual model integrating biological, physical and chemical distribution mechanisms. Mar. Pollut. Bull. 113, 7-16. https://doi.org/10.1016/ j.marpolbul.2016.10.002.

Vianello, A., Boldrin, A., Guerriero, P., Moschino, V., Rella, R., Sturaro, A., Da Ros, L., 2013. Microplastic particles in sediments of Lagoon of Venice, Italy: first observations on occurrence, spatial patterns and identification. Estuar. Coast Shelf Sci. 130, 54-61. https://doi.org/10.1016/j.ecss.2013.03.022.

Viehman, S., Vander Pluym, J.L., Schellinger, J., 2011. Characterization of marine debris in North Carolina salt marshes. Mar. Pollut. Bull. 62, 2771-2779. https:// doi.org/10.1016/j.marpolbul.2011.09.010.

Vroom, R.J.E., Koelmans, A.A., Besseling, E., Halsband, C., 2017. Aging of microplastics promotes their ingestion by marine zooplankton. Environ. Pollut. 231, 987-996. https://doi.org/10.1016/j.envpol.2017.08.088.

Wagner, M., Scherer, C., Alvarez-Muñoz, D., Brennholt, N., Bourrain, X., Buchinger, S., Fries, E., Grosbois, C., Klasmeier, J., Marti, T., Rodriguez-Mozaz, S., Urbatzka, R., Vethaak, A., Winther-Nielsen, M., Reifferscheid, G., 2014. Microplastics in freshwater ecosystems: what we know and what we need to know. Environ. Sci. Eur. 26 (12) https://doi.org/10.1186/s12302-014-0012-7.

Waite, H.R., Donnelly, M.J., Walters, L.J., 2018. Quantity and types of microplastics in the organic tissues of the eastern oyster Crassostrea virginica and Atlantic mud crab Panopeus herbstii from a Florida estuary. Mar. Pollut. Bull. 129, 179-185. https://doi.org/10.1016/j.marpolbul.2018.02.026.

Waldschläger, K., Lechthaler, S., Stauch, G., Schüttrumpf, H., 2020. The way of microplastic through the environment - application of the source-pathwayreceptor model (review). Sci. Total Environ. 713, 136584 https://doi.org/ 10.1016/j.scitotenv.2020.136584.

Wang, Fen, Wong, C.S., Chen, D., Lu, X., Wang, Fei, Zeng, E.Y., 2018. Interaction of toxic chemicals with microplastics: a critical review. Water Res. 139, 208-219. https://doi.org/10.1016/j.watres.2018.04.003.

Ward, R.D., 2020. Sedimentary response of Arctic coastal wetlands to sea level rise. Geomorphology 370, 107400. https://doi.org/10.1016/j.geomorph.2020.107400.

Ward, R.D., Lacerda, 2021. Responses of Mangrove Ecosystems to Sea Level Change. In: Friess, D., Sidik, F. (Eds.), Dynamic Sedimentary Environment of Mangrove Coasts. Elsevier, Netherlands. ISBN 9780128175101.

Ward, R.D., Teasdale, P.A., Burnside, N.G., Joyce, C.B., Sepp, K., 2014. Recent rates of sedimentation on irregularly flooded Boreal Baltic coastal wetlands: responses to recent changes in sea level. Geomorphology 217, 61-72. https://doi.org/ 10.1016/j.geomorph.2014.03.045.

Ward, R.D., Friess, D.A., Day, R.H., Mackenzie, R.A., 2016. Impacts of climate change on mangrove ecosystems: a region by region overview. Ecosyst. Heal. Sustain. 2, e01211. https://doi.org/10.1002/ehs2.1211.

Watson, R., Alder, J., Booth, S., Christensen, V., Kaschner, K., Kitchingman, A., Lai, S. Palomares, M., Valdez, F., Pauly, D., 2004. Launching our 'product' on the web. Sea Around Us Newsl 1-8. Welcome to www.seaaroundus.org.

Weinstein, J.E., Crocker, B.K., Gray, A.D., 2016. From macroplastic to microplastic: degradation of high-density polyethylene, polypropylene and polystyrene in a salt marsh habitat. Environ. Toxicol. Chem. 35, 1632-1640. https://doi.org/ 10.1002/etc.3432.

Wesch, C., Bredimus, K., Paulus, M., Klein, R., 2016. Towards the suitable monitoring of ingestion of microplastics by marine biota: a review. Environ. Pollut. 1-9. https://doi.org/10.1016/j.envpol.2016.08.076.

Willis, K.A., Denise Hardesty, B., Kriwoken, L., Wilcox, C., 2017a. Differentiating 
littering, urban runoff and marine transport as sources of marine debris in coastal and estuarine environments. Sci. Rep. 7, 1-9. https://doi.org/10.1038/ srep44479.

Willis, K.A., Eriksen, R., Wilcox, C., Hardesty, B.D., 2017b. Microplastic distribution at different sediment depths in an urban estuary. Front. Mar. Sci. 4, 1-8. https:// doi.org/10.3389/fmars.2017.00419.

Wolanski, E., Elliot, M., 2015. Estuarine Ecohydrology. Elsevier, Netherlands.

Wright, S.L., Rowe, D., Thompson, R.C., Galloway, T.S., 2013a. Microplastic ingestion decreases energy reserves in marine worms. Curr. Biol 23, R1031-R1033. https://doi.org/10.1016/j.cub.2013.10.068.

Wright, S.L., Thompson, R.C., Galloway, T.S., 2013b. The physical impacts of microplastics on marine organisms: a review. Environ. Pollut 178, 483-492. https:// doi.org/10.1016/j.envpol.2013.02.031.

Writer, H., Ryan, J.N., Barber, L.B., 2011. Role of biofilms in sorptive removal of steroidal hormones and 4-nonylphenol compounds from streams, pp. 7275-7283. https://doi.org/10.1021/es2008038.

Wu, C., Zhang, K., Huang, X., Liu, J., 2016. Sorption of pharmaceuticals and personal care products to polyethylene debris. Environ. Sci. Pollut. Res. 23, 8819-8826. https://doi.org/10.1007/s11356-016-6121-7.

Xu, B., Liu, F., Brookes, P.C., Xu, J., 2018. Microplastics play a minor role in tetracycline sorption in the presence of dissolved organic matter. Environ. Pollut. 240, 87-94. https://doi.org/10.1016/j.envpol.2018.04.113.

Xu, X., Jian, Y., Xue, Y., Hou, Q., Wang, L., 2019. Microplastics in the wastewater treatment plants (WWTPs): occurrence and removal. Chemosphere 235, 1089-1096. https://doi.org/10.1016/J.CHEMOSPHERE.2019.06.197.
Ye, S., Andrady, A.L., 1991. Fouling of floating plastic debris under Biscayne Bay exposure conditions. Mar. Pollut. Bull. 22, 608-613. https://doi.org/10.3892/ mmr.2015.4658.

Zalasiewicz, J., Waters, C.N., Ivar do Sul, J.A., Corcoran, P.L., Barnosky, A.D., Cearreta, A., Edgeworth, M., Gałuszka, A., Jeandel, C., Leinfelder, R., McNeill, J.R., Steffen, W., Summerhayes, C., Wagreich, M., Williams, M., Wolfe, A.P., Yonan, Y. 2016. The geological cycle of plastics and their use as a stratigraphic indicator of the Anthropocene. Anthropocene 13, 4-17. https://doi.org/10.1016/ j.ancene.2016.01.002.

Zardus, J.D., Nedved, B.T., Huang, Y., Tran, C., Hadfield, M.G., 2008. Microbial biofilms facilitate adhesion in biofouling invertebrates. Biol. Bull. 214, 91-98. https:// doi.org/10.2307/25066663.

Zettler, E.R., Mincer, T.J., Amaral-Zettler, L.A., 2013. Life in the "plastisphere": microbial communities on plastic marine debris. Environ. Sci. Technol. 47, 7137-7146. https://doi.org/10.1021/es401288x.

Zhao, S., Zhu, L., Wang, T., Li, D., 2014. Suspended microplastics in the surface water of the Yangtze Estuary System, China: first observations on occurrence, distribution. Mar. Pollut. Bull. 86, 562-568. https://doi.org/10.1016/ j.marpolbul.2014.06.032.

Zhao, S., Zhu, L., Li, D., 2015. Microplastic in three urban estuaries, China. Environ. Pollut 206, 597-604. https://doi.org/10.1016/j.envpol.2015.08.027.

Zhou, Y., Meng, J., Zhang, M., Chen, S., He, B., Zhao, H., Li, Q., Zhang, S., Wang, T., 2019. Which type of pollutants need to be controlled with priority in wastewater treatment plants: traditional or emerging pollutants? Environ. Int. 131, 104982. https://doi.org/10.1016/J.ENVINT.2019.104982. 